\title{
Kilka aspektów szkodliwego działania na drewniane obiekty polichromowane roztworów toluenowych stosowanych w zabiegach impregnacji wzmacniającej"
}

\section{Zagadnienia wstępne}

Pojęcie zabiegu impregnacji. Mechanizm przenikania roztworów

Pojęcie impregnacji wzmacniającej drewna określa zabieg polegający 1 na przesyceniu całej jego struktury, bez względu na różny stopień zniszczenia poszczególnych partii, substancjami utwardzającymi. Impre-

* Prezentowane w artykule wyniki zostały uzyskane w rezultacie zastosowania toluenu, powszechnie używanego w praktyce konserwatorskiej rozpuszczalnika impregnatów, jako materiału porównawczego i punktu odniesienia w badaniach nad możliwościami wykorzystania jako rozpuszczalników w roztworach impregnatów, wzmacniających zniszczone polichromowane drewno zabytkowe, eterów glikolu propylenowego. Zob. K. Szczepińska, Dobór rozpuszczalników żywic o optymalnych właściwościach do wzmacniania drewnianej rzeźby polichromowanej, rozprawa doktorska przygotowana pod kier. prof. dr art. kons. Bogumiły Rouby, Uniwersytet Mikołaja Kopernika, Wydział Sztuk Pięknych, Instytut Zabytkoznawstwa i Konserwatorstwa, Toruń 2007. 
gnat, osadzając się głęboko w strukturze drewna, skleja produkty powstające w wyniku procesów przemian i niszczącego działania szkodników biologicznych, częściowo lub całkowicie wypełnia wolne przestrzenie stałymi uformowaniami tworzywa.

Takie rozumienie zabiegu impregnacji wzmacniającej można spotkać w licznych opracowaniach dotyczących problematyki konserwacji drewna ${ }^{1}$.

Impregnacja, jako jedno $z$ podstawowych działań w konserwacji zniszczonych drewnianych obiektów zabytkowych, ma na celu przede wszystkim zahamowanie procesów niszczenia oraz poprawę właściwości fizycznych i wytrzymałościowych drewna².

1 U. Bieszczad, Wymiana zniszczonego drewna rzeźby polichromowanej na piankę poliuretanowa, praca magisterska napisana pod kier. dr Bożeny Soldenhoff w Zakładzie Konserwacji Malarstwa i Rzeźby Polichromowanej Instytutu Zabytkoznawstwa i Konserwatorstwa UMK, Torun 1982, s. 9 [mps przechowywany w bibliotece ZKMiRP, nr 102]; J. Lehmann, Konserwacja drewnianych zabytków etnograficznych $i$ archeologicznych. Badania i prace nad metodyka, „Ochrona Zabytków”, 1992, nr 1, s. 25; M. Makowska, Problemy konserwacji i restauracji rzeźby drewnianej polichromowanej na przykładzie krucyfiksu z Izbicy Kujawskiej, praca magisterska napisana pod kier. doc. dr hab. Marii Roznerskiej w Zakładzie Konserwacji Malarstwa i Rzeźby Polichromowanej Instytutu Zabytkoznawstwa i Konserwatorstwa UMK, Toruń 1985, s. 33 [mps przechowywany w bibliotece ZKMiRP, nr 116]; M. Malarska, Metody konserwacji podobrazi drewnianych na podstawie literatury oraz realizacji konserwatorskich w Zakładzie Konserwacji Malarstwa i Rzeźby Polichromowanej w Toruniu, praca magisterska napisana pod kier. dr Bożeny Soldenhoff w Zakładzie Konserwacji Malarstwa i Rzeźby Polichromowanej Instytutu Zabytkoznawstwa i Konserwatorstwa UMK, Toruń 2000, s. 55 [mps przechowywany w bibliotece ZKMiRP, nr 207]; E. Małachowicz, Konserwacja i rewaloryzacja architektury w zespołach i krajobrazie, Warszawa 1994, s. 79; M. Paciorek, Badania wybranych tworayw termoplastycznych stosowanych do impregnacji drewna, „Studia i Materiały Wydziału Konserwacji i Restauracji Dzieł Sztuki Akademii Sztuk Pięknych w Krakowie", 1993, t. 3, s. 7-8; B. Soldenhoff, Wrmacnianie drewna żywicami termoplastycznymi, [w:] Chemia w konserwacji zabytków. Materiaty z II Ogólnopolskiego Zjazdu Chemików Konserwatorów, Toruń-Bachotek, wrzesień 1981, Warszawa 1982, s. 48; W. Ślesiński, Konserwacja zabytków sz̨tuki, t. 3: Rzemiosto artystyczne, Warszawa 1995, s. 21; K. Wieczorek, Krajowe środki do ocbrony i konserwacji drewna w zabytkach, Warszawa 1992, s. 79.

2 U. Bieszczad, op. cit., s. 9; J. Jasieńko, Połaczenia klejowe $i$ inżynierskie w naprawie, konserwacji i wąmacnianiu zabytkowych konstrukecji drewnianych, Wrocław 2003, s. 14; 
Przenikanie roztworów impregnacyjnych w zdrowym drewnie następuje na skutek działania sił kapilarnych, praktycznie tylko wzdłuż włókien, przez powierzchnie przekroju poprzecznego ${ }^{3}$. W zniszczonym i spękanym drewnie obiektów zabytkowych impregnaty moga wnikać nawet na znaczna głębokość także przez przekroje boczne. Proces ten jest uzależniony od rodzaju i głębokości zniszczeń. Jednakże i tu dominujący wpływ ma charakterystyczny dla drewna kierunek przenikania roztworów ${ }^{4}$.

M. Kiepuszewska, M. Roznerska, Próba identyfikacji substancji wæmacniajacych drewno prayy usyciu zapisu rentgenograficznego, „Acta Universitatis Nicolai Copernici. Zabytkoznawstwo i Konserwatorstwo", 1993, t. 20, s. 147; W. Kurpik, Ekstrakcja impregnatu z rzeźby polichromowanej, praca magisterska napisana w Katedrze Technologii i Technik Malarskich Studium Zabytkoznawstwa i Konserwatorstwa przy Wydziale Sztuk Pięknych UMK, Torun 1962, s. 1 [mps przechowywany w bibliotece ZKMiRP, nr 24]; idem, Rozmieszcrenie spoin w czasie wysychania mas trocinowych, [w:] Zabytkowe drewno: konserwacja i badania, Warszawa 1987, s. 117; J. Lehmann, Konserwacja drewnianych zabytkón, s. 25; S. Łagoda, Problem impregnacji (konserwacji) oraz estetycznego opracowania (restauracji) dwóch rzeźb (barokowej i gotyckiej) drewnianych polichromowanych z muzeum ze Szczecina i Olsztyna, praca magisterska napisana pod kier. prof. dr Marii Roznerskiej w Zakładzie Konserwacji Malarstwa i Rzeźby Polichromowanej, Uniwersytet Mikołaja Kopernika, Torun 1997, s. 18 [mps przechowywany w bibliotece ZKMiRP, nr 193]; M. Makowska, op. cit., s. 33; M. Mietlicka, Badania nad efektywnościa zabiegów impregnacji wzmacniającej podobrazi drewnianych, praca magisterska napisana pod kier. dr Bożeny Soldenhoff w Zakładzie Konserwacji Malarstwa i Rzeźby Polichromowanej Uniwersytetu Mikołaja Kopernika w Toruniu, Toruń 1998, s. 4 [mps przechowywany w bibliotece ZKMiRP, nr 203]; M. Paciorek, Badania, s. 8; K. Sibul, Materials Used in Conservation of Painted Wooden Objects in Estonia, [w:] Materiaty z konferencii ARLADNE NR 10, Praga 22-28.04.2002, s. 3; B. Soldenhoff, Wryacnianie drewna ṡynicami, s. 48; W. Ślesiński, Konserwacja zabytkón sz̨tuki, t. 1: Malarstwo sżtalugowe i ścienne, Warszawa 1989, s. 21; idem, Konserwacja zabytkón sžtuki, t. 2: Rzę́ba, Warszawa 1990, s. 19; K. Wieczorek, op. cit., s. 79.

3 Adhesives and Coatings, Conservation Science Teaching Series, Science for Conservators, vol. 3, Frome and London 1994, s. 124; W. Domasłowski, Zagadnienie konserwacji drewna, „Materiały Zachodnio-Pomorskie”, 1958, t. 4, s. 47; R. Kawczyński, Nasycanie drewna środkami chemičnymi, Warszawa 1972, s. 107; M. Paciorek, Badania, s. 62; B. Soldenhoff, Wrmacnianie drewna roztworami symic termoplastycznych, „Acta Universitatis Nicolai Copernici. Zabytkoznawstwo i Konserwatorstwo", 1987, t. 11, s. 86; eadem, Wzmacnianie drewna symicami, s. 49; K. Wieczorek, op. cit., s. 80.

4 B. Soldenhoff, Wrmacnianie drewna symicami, s. 49-50. 
Mówiąc o impregnacji wzmacniającej drewnianych polichromowanych obiektów zabytkowych, należy pamiętać o ich złożonej budowie technicznej i technologicznej - drewno stanowi jedynie podłoże pod opracowanie malarskie i pozłotnicze, które zarówno w trakcie, jak i po zabiegu (podczas odparowywania lotnych składników impregnatu) jest narażone na kontakt $z$ użytym roztworem.

\section{Rozpuszczalniki impregnatów}

Rozpatrując zagadnienia związane z impregnacją wzmacniająca drewna, literatura przedmiotu zdecydowanie mniej miejsca poświęca rozpuszczalnikom i rozcieńczalnikom, koncentrując się na stosowanych tworzywach i metodach. Jest to, jak się wydaje, słuszne i uzasadnione, gdyż w roztworze impregnatu rola rozpuszczalników i rozcieńczalników jest podrzędna, niejako służebna wobec roli żywicy. Rozpuszczalnik ma zapewnić jej wprowadzenie do nasycanego obiektu. Rozmieszczenie i sposób związania żywicy z porowatą strukturą drewna to już procesy bardziej złożone, a właściwości rozpuszczalnika są tylko jednym z czynników warunkujących ich przebieg. Jednak, jak słusznie zauważaja badacze tematu, czynnik ten, kształtując cechy roztworu, wpływa również na powodzenie zabiegu impregnacji $1^{5}$.

5 J. Ciabach, Wtaściwości ànic sztucznych stosowanych w konserwacji zabytków, Toruń 1997, s. 32; M. Czajnik, Środki i metody konserwacji zabytkowego drewna budowlanego, „Ochrona Zabytków”, 1968, nr 1, s. 26; C. V. Horie, Materials for Conservation, Butterwarths-London-Boston-Durban-Singapore-Sydney-Toronto-Wellington 1978, s. 65-66; M. Malarska, op. cit., s. 64; D. E. Olczak, Metody i środki konserwacji polichromowanych rzeźb drewnianych oraz ich zastosowanie w Zakładzie Konserwacji Malarstwa i Rzeźby Polichromowanej, praca magisterska napisana pod kier. doc. dr hab. Marii Roznerskiej w Zakładzie Konserwacji Malarstwa i Rzeźby Polichromowanej Instytutu Zabytkoznawstwa i Konserwatorstwa UMK, Toruń 1985, s. 54 [mps przechowywany w bibliotece ZKMiRP, nr 115]; M. Paciorek, Badania, s. 9; idem, Zastosowanie tomografii komputerowej do badania rozmieszczenia $i$ udziału tworaywa w drewnie impregnowanym strukturalnie, Czterdziestolecie Wydziału Konserwacji Dzieł Sztuki ASP w Krakowie (1950-1990), „Biblioteka Muzealnictwa i Ochrony Zabytków”, 1992, seria B, t. 88, s. 212; idem, Zastosowanie tomografii komputerowej do badania rozmieszrzenia i udzialu tworzywa $w$ drewnie impregnowanym strukturalnie, „Ochrona Zabytków”, 1992, 
Przez pojęcie rozpuszczalnika rozumie się substancje ciekłe, związki chemiczne organiczne lub nieorganiczne lub ich mieszaniny, zdolne do rozpuszczania innych substancji w dowolnym lub ograniczonym stosunku ilościowym, z wytworzeniem układów jednorodnych roztworów ${ }^{6}$.

Rozpuszczalniki można podzielić na nieorganiczne i organiczne, wśród których należy wyróżnić: węglowodory, chlorowane węglowodory, alkohole, ketony, kwasy organiczne, etery i polietery, pochodne furanu oraz rozpuszczalniki będące mieszaninami związków organicznych ${ }^{7}$.

Powszechną klasyfikacją ze względu na właściwości jest podział rozpuszczalników na polarne i niepolarne. Pierwsze to ciecze o znacznej stałej dielektrycznej, w których występowanie grup funkcyjnych umożliwia powstawanie wiązań koordynacyjnych. Należą do nich woda, kwasy, niższe alkohole, glikole, aminy, amidy, nitrozwiązki. Mianem niepolarnych określa się ciecze o niewielkiej stałej dielektrycznej, niemające aktywnych grup funkcyjnych, takie jak węglowodory i chlorowcopochodne alkilowe $e^{8}$.

Rozpuszczalniki sa też klasyfikowane w zależności od temperatury wrzenia na:

- niskowrzace - o temperaturze wrzenia poniżej $100^{\circ} \mathrm{C}$,

- średniowrzace - od 100 do $150^{\circ} \mathrm{C}$,

- wysokowrzace - od 150 do $250^{\circ} \mathrm{C}^{9}$.

nr 3, s. 159; W. Ślesiński, Konserwacja zabytkón sætuki, t. 2, s. 19; idem, Konserwacja zabytków squtuki, t. 3, s. 21.

6 T. Drapała, Chemia fisyczna z zadaniami, Warszawa-Poznań 1982, s. 134; Encyklopedia fizyki, t. 3: P-Ż, Warszawa 1974, s. 238; Encyklopedia techniki. Chemia, Warszawa [1993], s. 642; R. L. Feller, N. Stolow, E. H. Jones, On picture varnishes and their solvents, Washington 1985, s. 25; Leksykon naukowo-techniczny, Warszawa 2001, s. 902 , 905; Lösungsmittel in der Restaurierung, Wien 1984, s. 17; Maty stownik chemiczny, Warszawa 1974, s. 459; Stownik chemii praketycznej, Warszawa 1992, s. 350; Stownik encyklopedyczny. Chemia, Wrocław 2001, s. 486, 488; D. Stoye, Paints, Coatings and Solvents, Weinheim 1993, s. 275; The Encyclopedia of Chemistry, New York-Cincinnati-Toronto-London-Melbourne 1973, s. 1025.

7 Stownik chemii, s. 350.

8 Encyklopedia firyki, s. 238; Maty stownik, s. 459; The Encyclopedia, s. 1026-1027.

9 B. Slánský, Technika malarstwa, t. 1: Materiały do malarstwa i konserwacji, [Warszawa] 1960, s. 112. 
Temperatura wrzenia daje tylko przybliżona informację o lotności i szybkości odparowywania cieczy. Generalnie wśród rozpuszczalników o podobnej budowie i właściwościach chemicznych lotność maleje ze wzrostem temperatury wrzenia, natomiast w przypadku jej równych wartości, cechujących zróżnicowane pod względem chemicznym rozpuszczalniki, wolniej odparowuja te $\mathrm{z}$ nich, które tworzą wiązania wodorowe, na przykład alkohole czy aminy. Szybkość, z jaka rozpuszczalnik odparowuje, zależy, poza lotnościa, od takich czynników, jak: prężność par w temperaturze, w której zachodzi proces, ciepło odparowywania, napięcie powierzchniowe, masa cząsteczkowa rozpuszczalnika, entalpia odparowywania, ruchy i wilgotność powietrza oraz obecność substancji rozpuszczonej. Czynniki te są wzajemnie ze soba powiązane. W praktyce czas odparowywania konkretnej ilości rozpuszczalnika jest określany eksperymentalnie, w identycznych warunkach i porównywany z uzyskanym dla eteru (eter $=1)$ lub octanu n-butylu (octan n-butylu $=1)^{10}$.

Pod względem lotności rozpuszczalniki można podzielić na cztery grupy (eter $=1)$ :

- o wysokiej lotności < 10,

- o średniej lotności 10-35,

- o niskiej lotności 35-50,

- o bardzo niskiej lotności > 50 .

W odniesieniu do octanu n-butylu = 1 wyróżnia się:

- klasa 1: rozpuszczalniki szybko (gwałtownie) odparowujące $>3,0$;

- klasa 2: rozpuszczalniki umiarkowanie odparowujące 0,8-3,0;

- klasa 3: rozpuszczalniki powoli odparowujące $<0,8$.

Ogólną cechą rozpuszczalników jest zdolność rozpuszczania określonych substancji. Jest ona związana $z$ ich fizykochemicznymi właściwościami, które powinny być zbliżone do właściwości substancji rozpuszczanej. Ciecze polarne o dużej stałej dielektrycznej są zwykle dobrymi rozpuszczalnikami dla innych substancji polarnych oraz dla elektrolitów. Mniej polarne rozpuszczalniki, zwłaszcza związki organiczne, zawierające polarne grupy funkcyjne (alkohole, ketony, amidy, etery, estry), rozpuszczaja związki o podobnej polarności. Substancje o niskiej polarności lub

10 C. V. Horie, op. cit., s. 58; D. Stoye, op. cit., s. 292-293. 
niepolarne rozpuszczają się dobrze w węglowodorach i chlorowanych węglowodorach. Zasada „podobne rozpuszcza się w podobnym” wydaje się obowiazująca ${ }^{11}$.

Polimery sa zdolne do rozpuszczania w cieczach o małej masie cząsteczkowej. Jednak duże rozmiary makroczasteczek polimerów w porównaniu z rozmiarami cząsteczek rozpuszczalnika sprawiaja, że zarówno ich proces rozpuszczania, jak i właściwości roztworów różnią się od procesu rozpuszczania i właściwości roztworów substancji małocząsteczkowych.

Rozpuszczanie polimeru jest powolnym, dwuetapowym procesem. W pierwszym etapie cząsteczki rozpuszczalnika, których ruchliwość wielokrotnie przewyższa ruchliwość makroczasteczek polimeru, wnikaja (dyfunduja) do wnętrza tego ostatniego, początkowo do jego warstwy zewnętrznej, później do głębszych. Polimer pęcznieje, jego makrocząsteczki stopniowo oddalają się od siebie. Tworzy się coś, co - jak pisze J. Ciabach - „można by nazwać roztworem cieczy w polimerze”. Jeżeli siły oddziaływań między fragmentami łańcuchów są większe niż siły oddziaływań między polimerem a cząsteczkami rozpuszczalnika, polimer pozostaje w stanie spęcznianym. Efekt ten występuje w przypadku polimerów usieciowanych, pod warunkiem, że stopień usieciowania nie jest zbyt duży. Jeżeli oddziaływania polimeru z rozpuszczalnikiem dominuja, to zachodzi drugi etap rozpuszczania - spęczniany żel przechodzi powoli w roztwór ${ }^{12}$.

Analizując oddziaływania polimeru z rozpuszczalnikiem, literatura przedmiotu wprowadza pojęcie rozpuszczalników dobrych, obojętnych i złych. W rozpuszczalnikach dobrych siły oddziaływań między segmentami polimerowymi i cząsteczkami rozpuszczalnika są większe niż między segmentami polimerowymi. W rozpuszczalnikach złych siły oddziaływań

11 Encyklopedia fizyki, s. 238; Z. Jerzmanowska, Analiza jakościowa zwiqzków organicznych, Warszawa 1975, s. 38; Maty stownik, s. 459; Stownik chemii, s. 351; Stownik encyklopedyczny, s. 486; D. Stoye, op. cit., s. 276; K. Wieczorek, op. cit., s. 182.

12 J. Ciabach, Wtaściwości ṡywic, s. 31, 101; C. V. Horie, op. cit., s. 67-68; Mały stownike, s. 461; Podstawy recyklingu tworzyw sztucznych, pod red. M. Kozłowskiego, Wrocław 1998, s. 27; S. Porejko, J. Fejgin, L. Zakrzewski, Chemia zwiqzków wielkoczasteczkowych, Warszawa 1972, s. 137-138; W. Przygocki, Metody fizyczne badan polimerów, Warszawa 1990, s. 35; J. F. Rabek, Podstawy fizykochemii polimerów, Wrocław 1977, s. 21; D. Stoye, op. cit., s. 288; M. E. Witkowie, Podstawy chemii i przetwórstwa polimerów wraz z ćniczeniami laboratoryjnymi, Łódź 1978, s. 405. 
polimer-polimer przewyższają siły oddziaływań polimer-rozpuszczalnik. W rozpuszczalnikach obojętnych, zwanych też idealnymi lub $\theta$, siły te są jednakowe ${ }^{13}$.

Rozważania dotyczące rozpuszczania polimerów najwygodniej jest oprzeć na podstawach termodynamiki. Są to jednak zagadnienia zbyt obszerne, aby mogły zostać tutaj szerzej omówione ${ }^{14}$.

Użyteczna przydatność wszystkich rozpuszczalników określają między innymi: temperatura wrzenia, szybkość parowania, lotność, temperatura zapłonu, palność, aktywność chemiczna, odporność na działanie czynników zewnętrznych (samoutlenialność), toksyczność, barwa, zapach, stopień czystości ${ }^{15}$. Wszystkie te cechy powinny być rozpatrywane łącznie, gdyż z faktu, że dla danej żywicy dany rozpuszczalnik jest termodynamicznie dobry, nie wynika jednoznacznie, że roztwór w nim będzie miał zastosowanie praktyczne, gdyż może on być za drogi, trudno dostępny, zbyt toksyczny lub zbyt łatwopalny ${ }^{16}$.

Wybór rozpuszczalnika impregnatu drewnianego obiektu zabytkowego, szczególnie polichromowanego, jest problemem złożonym i dla każdego z poddawanych impregnacji zabytków musi być dokonywany ponownie, $z$ uwzględnieniem indywidualnych cech obiektu i zakresu ingerencji17.

13 J. Ciabach, Wtaściwości żywic, s. 31, 101; Cleaning, Conservation Science Teaching Series, Science for Conservators, vol. 2, Frome and London 1992, s. 54-57; Encyklopedia fizyki, s. 255; R. L. Feller, N. Stolow, E. H. Jones, op. cit., s. 30, 33, 90; Lösungsmittel, s. 91; H. Mark, A. V. Tobolsky, Chemia fizyczna polimerów, Warszawa 1957, s. 261; J. Ostrowska, B. Ostrowska-Gumkowska, W. Czerwiński, G. Lemańska, Podstawy chemii i fiaylkochemii polimerów, pod red. A. Narębskiej, Toruń 1984, s. 171-172; Podstawy recyklingu, s. 27, 29; S. Porejko, J. Fejgin, L. Zakrzewski, op. cit., s. 138-140; W. Przygocki, A. Włochowicz, Fiaylka polimerów. Wybrane zagadnienia, Warszawa 2001, s. $41-42$.

14 Zagadnienie to autorka omówiła, na podstawie literatury przedmiotu, w swej rozprawie doktorskiej, zob. K. Szczepińska, op. cit., s. 78-81. Tam też literatura dotycząca tego tematu.

15 Encyklopedia techniki, s. 642; C. V. Horie, op. cit., s. 52; Stownik chemii, s. 351.

16 J. Ciabach, Wtaściwości żywic, s. 32.

17 S. M. Carlson, A. P. Schniewid, Residual solvents in wood-consolidant composites, „Studies in Conservation”, 1990, no. 1, s. 31; Y. Wang, A. P. Schniewind, Consolidation of deteriorated wood with soluble resins, „Journal of the American Institute for Conservation", 1985, no. 2, s. 77-91. Podaję na podstawie informacji zawartych na stronie: http://www.bcin.ca (dostęp: 5.01.2005). 
Publikacje z zakresu impregnacji wzmacniającej drewna podejmuja próby określenia cech odpowiedniego do tego celu rozpuszczalnika. Generalnie uważa się, że należy stosować rozpuszczalniki:

- czyste i bezbarwne, odparowujące bez pozostałości ${ }^{18}$,

- niespecczniające drewna ${ }^{19}$,

- mające zdolność całkowitego rozpuszczania żywicy i tworzenia z nią roztworów o małej lepkości ${ }^{20}$,

- cechujące się dobrą zwilżalnością w stosunku do drewna, czyli niskim napięciem powierzchniowym ${ }^{21}$,

18 D. Stoye, op. cit., s. 275.

19 B. Chaber, Badania nad impregnacją desek podobrazi roztworami żywicy epoksydowej Epidian 5, praca magisterska wykonana pod kier. doc. dr. W. Domasłowskiego w Katedrze Technologii i Technik Malarskich Wydziału Sztuk Pięknych UMK, Toruń, s. 8, 16 [mps przechowywany w bibliotece ZKMiRP, nr 47]; M. Czajnik, Środki, s. 26; W. Domasłowski, Konserwacja (wrmacnianie, utwardzanie) drewna pod zmniejszonym ciśnieniem, „Biblioteka Muzealnictwa i Ochrony Zabytków. Zagadnienia Konserwacji Drewna”, seria B, t. 3, Warszawa 1961, s. 51; idem, Zagadnienie, s. 401; M. Kiepuszewska, M. Roznerska, op. cit., s. 150; A. Lisewska, Konserwacja rzeźby drewnianej polichromowanej, praca magisterska, Toruń 1962, s. 48 [mps przechowywany w bibliotece ZKMiRP, nr 23]; M. Mietlicka, op. cit., s. 68; R. Munnikendam, Consolidation of fragile wood with low viscosity aliphatic epoxy resins, [w:] Conservation of Wood in Painting and the Decorative Arts, Preprints of the Contributions to the Oxford Congress, 17-23 September 1978, London 1978, s. 71; D. E. Olczak, op. cit., s. 54; B. Soldenhoff, Wrimacnianie drewna ro:tworami, s. 82.

20 M. Czajnik, Środki, s. 26; idem, Konservacja drewna zabytkowego w polskich parkach etnograficznych, [w:] Ogólnopolska Konferencja Muzeón i Parków Etnograficznych, Opole 22-24 IX 1970 rok, Opole 1971, s. 130; W. Domasłowski, Konserwacja, s. 52; idem, Zagadnienie, s. 401; C. V. Horie, op. cit., s. 66; M. Kiepuszewska, M. Roznerska, op. cit., s. 150; A. Lisewska, op. cit., s. 48; M. Mietlicka, op. cit., s. 68; S. M. Nakhla, A comparative study of resins for the consolidation of wooden objects, „Studies in Conservation”, 1986, no. 1, s. 38; D. E. Olczak, op. cit., s. 54; K. Wieczorek, op. cit., s. 82. Lepkość uzyskiwanych roztworów jest również miarą zdolności rozpuszczania żywicy przez użyty rozpuszczalnik. Im rozpuszczalnik mocniejszy (termodynamicznie lepszy), tym mniejsza jest lepkość roztworu. Zob.: J. Ciabach, Wtaściności ṡynic, s. 31; W. Domasłowski, Konserwacja, s. 53; W. Przygocki, op. cit., s. 35.

21 M. Czajnik, Konserwacja, s. 130; W. Kurpik, Utwardzanie zniszzzonego drewna pray pomocy symic syntetycznych. Wykonywanie plomb trocinowych, „Materiały Muzeum Budownictwa Ludowego w Sanoku”, 1966, nr 6, s. 27; K. Wieczorek, op. cit., s. 182. 
- niewykazujące aktywności chemicznej i w żaden sposób nieoddziałujące szkodliwie na składniki drewna, warstwy zapraw, polichromii i złoceńn ${ }^{22}$,

- w jak najmniejszym stopniu rozpuszczające i przenoszace naturalne składniki drewna, takie jak żywice, woski, barwniki, garbniki itp. ${ }^{23}$,

- mające odczyn obojętny,

- mające niska palność ${ }^{4}$,

- nietoksyczne ${ }^{25}$.

\section{Toluen - rozpuszczalnik powszechnie stosowany w impregnatach wzmacniających drewno zabytkowe}

Toluen $\mathrm{C}_{6} \mathrm{H}_{5} \mathrm{CH}_{3}$ - metylobenzen, węglowodór aromatyczny, najprostszy homolog benzenu - jest bezbarwna, palną cieczą o charakterystycznym zapachu. Jego temperatura topnienia wynosi $-95^{\circ} \mathrm{C}$, wrzenia $110,6^{\circ} \mathrm{C}$. Nie rozpuszcza się w wodzie, rozpuszcza w alkoholach i węglowodorach. Jest otrzymywany przez katalityczne reformowanie ropy naftowej lub destylację frakcyjną smoły pogazowej ${ }^{26}$. Gęstość toluenu wynosi $0,878 \mathrm{~g} / \mathrm{cm}^{3}$, lepkość $0,61 \mathrm{mPa} \cdot \mathrm{s}$, lotność 6,1 (dla eteru = 1) lub 2,0 (dla octanu n-butylu = 1), prężność par $2,9 \mathrm{kPa} w 20^{\circ} \mathrm{C}$. Jego parametry rozpuszczalności wynoszą $\delta_{\mathrm{d}}=80 ; \delta_{\mathrm{p}}=7,0 ; \delta_{\mathrm{h}}=13^{27}$.

22 B. Chaber, op. cit., s. 16; M. Malarska, op. cit., s. 64; M. Mietlicka, op. cit., s. 69; R. Munnikendam, op. cit., s. 71; S. M. Nakhla, op. cit., s. 38; D. E. Olczak, op. cit., s. 54.

23 M. Mietlicka, op. cit., s. 69.

24 M. Czajnik, Środki, s. 26; W. Domasłowski, Konserwacja, s. 52; idem, Zagadnienie, s. 401; A. Lisewska, op. cit., s. 49; M. Mietlicka, op. cit., s. 68-69; D. Stoye, op. cit., s. 275 .

25 S. M. Nakhla, op. cit., s. 38; D. Stoye, op. cit., s. 275.

26 Encyklopedia dla wsyystkich. Chemia, Warszawa 2001, s. 386; Encyklopedia techniki, s. 756; K. H. Lautenschlänger, W. Schröter, A. Wanninger, Nowoczesne kompendium chemii, Warszawa 2007, s. 686; Leksylkon, s. 1092; Stownik encyklopedyczny, s. 558.

27 J. Ciabach, Wtaściwości ṡywic, s. 102; M. Paciorek, Badania, tabela własności rozpuszczalników 1, lp. 2; E. Szmit-Naud, Uzupetnianie ubytkón warstwy malarskiej obrazón - badania materiatón stosowanych wspótczésnie, „Acta Universitatis Nicolai Coper- 
Węglowodory aromatyczne, do których należy toluen, są uznawane za najodpowiedniejsze do głębokiej impregnacji ze względu na najmniejsze działanie spęczniające i obojętność w stosunku do drewna ${ }^{28}$.

Toluen jest wymieniany jako rozpuszczalnik, składnik mieszanin rozpuszczalników bądź rozcieńczalnik w roztworach wielu stosowanych historycznie i współcześnie żywic impregnatów, zarówno pochodzenia naturalnego, takich jak kalafonia ${ }^{29}$, damara ${ }^{30}$, mastyks ${ }^{31}$, jak i syntetycznych: hydrofobowych żywic aminowych ${ }^{32}$, cykloheksanonowych ${ }^{33}$, modyfikowanych żywic fenolowo-formaldehy-

nici. Zabytkoznawstwo i Konserwatorstwo", 2005, t. 34, s. 77, a także D. Stoye, op. cit., s. 324, który podaje inne wartości parametrów rozpuszczalności, a mianowicie: $\delta=18,2 ; \delta \mathrm{d}=18,0 ; \delta \mathrm{p}=1,4 ; \delta \mathrm{h}=2,0$.

28 M. Paciorek, Badania, s. 13; M. Czajnik, Konserwacja, s. 130; W. Domasłowski, Konserwacja, s. 49; idem, Zagadnienie, s. 402-403; W. Kurpik, Utwardzanie, s. 27; D. E. Olczak, op. cit., s. 54.

29 M. Doerner, Materiaty malarskie i ich zastosowanie, Warszawa 1975, s. 93; J. Hopliński, Farby i spoiwa malarskie, Wrocław-Kraków 1959, s. 51; A. Jędrzejewska, P. Rudniewski, A. Wawrzeńczak, Substancje sækodliwe dla zdrowia stosowane prayy konserwacji dziet sztuki, Warszawa 1974, s. 143; M. Kiepuszewska, M. Roznerska, op. cit., s. 153; J. Lehmann, Chemia malarstwa i jego konserwacji, „Biblioteka Muzealnictwa i Ochrony Zabytków”, 1974, seria B, t. 37, s. 70; B. Slánský, op. cit., s. 80-82, 87.

30 J. Ciabach, Badania dotyczace starženia $i$ stabilizacij wspótczesnych wernilesów malarskich, Toruń 1994, s. 70; idem, Damara na cen₹urowanym, „Biuletyn Informacyjny Konserwatorów Dzieł Sztuki”, 1992, nr 3-4, s. 15-16; J. Hopliński, op. cit., s. 52-53; A. Jędrzejewska, P. Rudniewski, A. Wawrzeńczak, op. cit., s. 142; J. Lehmann, Chemia, s. 71; B. Slánský, op. cit., s. 80, 83-84, 87; Spis dokumentacij konserwatorskich zabytków ruchomych, cz. 1: Dla zabytków znajdujacych sie poza muzeami, A-N, „Biblioteka Muzealnictwa i Ochrony Zabytków", 1975, seria B, t. 39, s. 109, 117, 170, 266; Spis dokumentacji konserwatorskich zabytków ruchomych, cz. 1: Dla zabytków znajdujacych sie poza muzeami, $O-\dot{Z}$, „Biblioteka Muzealnictwa i Ochrony Zabytków”, 1975, seria B, t. 39, s. 116.

31 M. Doerner, op. cit., s. 91; J. Hopliński, op. cit., s. 51-52; J. Lehmann, Chemia, s. 71; B. Slánský, op. cit., s. 80, 83, 87.

32 W. Domasłowski, Wtasności jyynic sztucznych oraz, ich zastosowanie do prac konserwatorskich, „Materiały Zachodnio-Pomorskie”, 1960, t. 6, s. 572-573, 576.

33 J. Ciabach, Badania, s. 73-76; idem, Fotooksydacyjne starzenie sie powtok werniksu końcowego Rembrandt S.3 firmy Talens, „Acta Universitatis Nicolai Copernici. Zabytkoznawstwo i Konserwatorstwo", 1990, t. 15, s. 24; idem, Wtaściwości i za- 
dowych, znanych pod nazwa albertole ${ }^{34}$, chlorowanego polichlorku winylu $^{35}$, polioctanu winylu ${ }^{36}$, kopolimeru chlorku winylu i eteru winy-

stosowanie synwic cykloheksanononych, „Ochrona Zabytków”, 1991, nr 3, s. 209; idem, Wtaściności synwic, s. 96-97; M. Czajnik, Środki, s. 25; W. Domasłowski, Konservacja, s. 54; E. R. de la Rie, A. M. Shedrinsky, The chemistry of ketone resins and the synthesis of the derivative with increased stability and flexibility, „Studies in Conservation”, 1989, no. 1, s. 9. O próbach, aczkolwiek nieudanych, zastosowania żywicy cykloheksanonowej Laropal K 80 do impregnacji zniszczonego drewna pisała E. Kaplan. Zob. informacje zawarte w abstrakcie publikacji E. Kaplan, A comparison of four consolidants for degraded wood, Kingston 1993, zamieszczonym na stronie http://www.bcin. ca (dostęp: 15.10.2004).

34 J. Ciabach, Wtaściwości ṡywic, s. 63; W. Domasłowski, Wtasności, s. 571-572; K. Dąbrowska, Konserwacja polichromii gotyckiej rzeźby drewnianej na podstawie przeprowadzonej konserwacji figury Matki Boskiej ze Słupcy, praca magisterska, Torun 1955, s. 92 [mps przechowywany w bibliotece ZKMiRP, nr 7]; A. Dworakowska, Konserwacja i ewentualna rekonstrukcja polichromii rzeźby drewnianej, praca magisterska, Zakład Technologii i Technik Malarskich Studium Konserwatorstwa i Muzealnictwa przy Wydziale Sztuk Pięknych Uniwersytetu Mikołaja Kopernika, Toruń 1955, s. 4, 33-34 [mps przechowywany w bibliotece ZKMiRP, nr 9]; eadem, Konserwacja XVI-wiecznego Krucyfiksu ₹ Maszewa, „Materiały Zachodnio-Pomorskie", 1956, t. 2, s. 313.

35 B. Chaber, op. cit., s. 10; J. Ciabach, Wtaściwości ṡymic, s. 46-47; M. Czajnik, Środki, s. 26; W. Domasłowski, Konserwacja, s. 54; idem Własności, s. 598-599; idem, Zagadnienie, s. 401, 404; C. V. Horie, op. cit., s. 32; A. Szczepkowski, Uzupetnianie drewnianych podobrazi i elementón rzę́biarskich w Pracowni Konserwacii MBL, „Materiały Muzeum Budownictwa Ludowego w Sanoku”, 1972, nr 16, s. 18.

36 Adhesives, s. 51; J. Ciabach, Wtaściwości s̀ynic, s. 47-48; M. Czajnik, Środki, s. 26; W. Domasłowski, Konserwacja, s. 54-55; H. Krach, Chemia stosowana w drzeewnictwie, Warszawa 1973, s. 233-234; K. A. Krzyżyński, Badania nad stabilizacja podobrazia drewnianego, praca magisterska napisana pod kier. doc. Jerzego Wolskiego przy Katedrze Technologii i Technik Malarskich Wydziału Sztuk Pięknych UMK, Torun 1968, s. 25-26 [mps przechowywany w bibliotece ZKMiRP, nr 41]; W. Kurpik, Ekstrakcja, s. 71; V. Kyzelyté, Możliwości wzmacniania płócien zabytkowych, praca magisterska napisana pod kier. prof. dr Bogumiły Rouby we współpracy z dr. hab. Jerzym Ciabachem, Wydział Sztuk Pięknych, Zakład Konserwacji Malarstwa i Rzeźby Polichromowanej UMK, Torun 2002, s. 59 [mps przechowywany w bibliotece ZKMiRP, nr 224]; W. Slesiński, Konserwacja zabyttón sətuki, t. 2, s. 22; K. Wieczorek, op. cit., s. 93. 
lowoizobutylowego (Vinoflex MP400) ${ }^{37}$, żywic epoksydowych ${ }^{38}$, żywic akrylowych ${ }^{39}$.

\section{Część badawcza}

Program badań został skonstruowany tak, aby objacć wachlarz zagadnień istotnych w oddziaływaniu drewno-impregnat, ze szczególnym naciskiem na użyty rozpuszczalnik.

Toluen zastosowano w połączeniu z żywicami akrylowymi: Paraloidem B-72 (kopolimer metakrylanu etylu 70\% i akrylanu metylu 30\%) i Osolanem K16 (48\% roztwór w toluenie kopolimeru metakrylanów metylu i butylu w stosunku 1:3).

W przeważającej części użyto drewna pochodzącego z obiektów zabytkowych. W celu maksymalnego zniwelowania różnic występujących pomiędzy poszczególnymi próbkami w obrębie każdej przygotowanej na potrzeby kolejnych badań grupy wybierano materiał jednolicie zniszczony i zazwyczaj pochodzacy z tego samego elementu.

37 B. Chaber, op. cit., s. 10; J. Ciabach, Wtaściwości żywic, s. 44; M. Czajnik, Środki, s. 26; W. Domasłowski, Konserwacja, s. 55; idem, Wlasności, s. 599; A. Lisewska, op. cit., s. 48; W. Ślesiński, Konserwacja zabytkón sztuki, t. 2, s. 22; idem, Konserwacja zabytków squtuki, t. 3, s. 21.

38 J. Ciabach, Wtaściwości żywic, s. 69-70; W. Domasłowski, K. Powidzki, Badania nad zastosowaniem roztworów symic epoksydowych do impregnacii (wamacniania) drewna, „Zeszyty Naukowe Uniwersytetu Mikołaja Kopernika w Toruniu”, 1968, z. 3, s. 196-197; W. Domasłowski, Własności, s. 580; J. Pielichowski, A. Puszyński, Technologia tworaynw sžtucznych, Warszawa 1994, s. 244; S. Jędrzejewska, P. Rudniewski, A. Wawrzeńczak, op. cit., s. 145; K. Wieczorek, op. cit., s. 149.

39 J. Ciabach, Właściwości s̀ywic, s. 55; W. Domasłowski, Własności, s. 585-586; C. V. Horie, op. cit., s. 103; V. Kyzelyté, op. cit., s. 47; M. Matuszczyk, Retusze na malowidłach ściennych $z$ wykorzystaniem wybranych spoiw akrylowych, praca magisterska napisana pod kier. prof. dr Marii Roznerskiej i mgr Ewy Roznerskiej-Świerczewskiej w Zakładzie Konserwacji Malarstwa i Rzeźby Polichromowanej UMK, Toruń 1997, s. 33 [mps przechowywany w bibliotece ZKMiRP, nr 195]; J. Pielichowski, A. Puszyński, op. cit., s. 122-123; A. I. Lazariew, M. F. Sorokin, Żywice syntetyczne, Warszawa 1957, s. 258. 
Wyniki wskazujące na szkodliwe działanie toluenu, stosowanego jako rozpuszczalnik impregnatów wzmacniających, uzyskano w badaniach rozmieszczenia wprowadzonego impregnatu i jego wpływu na warstwy malarskie. Zostaną one przedstawione poniżej.

\section{Badanie rozmieszczenia żywicy w impregnowanym drewnie}

Na rozmieszczenie tworzywa w drewnie wpływają reakcje chemicznej polimeryzacji i towarzyszace im zjawiska termiczne (w przypadku nasycania żywicami reaktywnymi i monomerami), a także fizyczne (w przypadku roztworów polimerów). Pierwszym ze zjawisk fizycznych jest początkowy efekt chromatograficzny, występujący wówczas, gdy z roztworu impregnatu drewno absorbuje więcej rozpuszczalnika lub rozpuszczonego w nim ciała stałego, albo też, jak w przypadku roztworów zbyt długo przechowywanych, gdy doszło do wytworzenia agregatów (mikrożeli) polimeru - pozostaja one w strefie przypowierzchniowej, a do wnętrza porowatej struktury drewna wnika prawie sam rozpuszczalnik. Drugim, bardziej znaczącym czynnikiem jest odparowywanie nieaktywnego rozpuszczalnika, nie tylko z drewna, ale również z żelu tworzywa, które w wyniku tego procesu przechodzi stopniowo w ciało stałe. Odparowujący rozpuszczalnik przemieszcza się z głębszych warstw ku powierzchni, pociagając za soba rozpuszczone tworzywo, co powoduje jego mniejszą lub większa migrację. Szybkość przemieszczania się rozpuszczalnika jest uzależniona głównie od jego lotności, aktywności chemicznej, lepkości roztworu oraz od ewentualnej różnicy temperatury otoczenia i przypowierzchniowych warstw drewna ${ }^{40}$, a także od budowy anatomicznej drewna obiektu; prze-

40 Adhesives, s. 212, 214; P. Buksalewicz, M. Gajdziński, K. Lutomski, Wærmacnianie drewna zabytkowego pray usyciu preparatów Petrifo i Paraloid, [w:] Zabytkowe drewno - konserwacja i badania, Warszawa 1987, s. 109; J. Bursze, Podtoża drewniane w malarstwie sz̧talugowym, Warszawa 1974, s. 23; M. Czajnik, Konserwacja, s. 130; P. Kotlik, Impregnation under low pressure, „Studies in Conservation”, 1998, no. 1, s. 42; W. Kurpik, Utwardzanie, s. 27; R. Munnikendam, op. cit., s. 71; U. Schessl, Probleme der Konservierungsstoffe zur Festigkeiterböhung von dekoratiertem Holz, [w:] Konservierung von Holzbauten, hrsg. von M. Bilfinger, D. Meili, Berlin-Stuttgart 1989, s. 98; B. Soldenhoff, Wzmacnianie drewna roztworami, s. 102; I. Swaczyna, Meble - naprawa i odnawianie, Warszawa 1995, 
mieszczanie odbywa się bowiem głównie przez powierzchnie przekroju poprzecznego ${ }^{41}$. W. Domasłowski i J. Łukaszewicz, analizując zjawisko migracji roztworów w materiale porowatym, stwierdzili, że o wielkości migracji decyduje ponadto zdolność roztworów do rozdziału faz, jaki zachodzi w materiale. Jest ona mniejsza dla rozpuszczalników dobrych ${ }^{42}$. Migracja to zjawisko negatywne i prowadzace do uszczelnienia oraz nadmiernego utwardzenia warstw przypowierzchniowych w stosunku do mniej przesyconych partii wewnętrznych i zwiększające tym samym niejednorodność materiału. Równocześnie wzrasta niebezpieczeństwo powstawania w drewnie wewnętrznych naprężeń, zostaje utrudnione przemieszczanie się wilgoci, co oczywiście może powodować uaktywnienie się procesów niszczenia ${ }^{43}$.

Trzeba też pamiętać, że drewno obiektów zabytkowych, ze względu na swą budowę i wynikająca z niej niejednorodność, pogłębioną w historii obiektów działaniem wszelkiego rodzaju procesów niszczących,

s. 66; W. Ślesiński, Konserwacja zabytków sz̧tuki, t. 2, s. 20; K. Wieczorek, op. cit., s. 80, 187.

41 B. Soldenhoff, Wrmacnianie drewna roztworami, s. 102; K. Wieczorek, op. cit., s. 80 .

42 W. Domasłowski, J. Łukaszewicz, Badania nad strukturalnym wżmacnianiem wapienia pińczowskiego termoplastycznymi żyicami sztucznymi, cz. 4: Wyjaśnienie prayczynn migracji żyic, „Acta Universitatis Nicolai Copernici. Zabytkoznawstwo i Konserwatorstwo", 1983, t. 10, s. 28, 32, 44-45; iidem, Badania nad strukturalnym wæmacnianiem wapienia pinczowskiego termoplastycznymi zymicami sztucznymi, cz. 3: Badania nad zastosowaniem ṡywicy Paraloid B-72 oraz,polimetakrylanu metylu, „Acta Universitatis Nicolai Copernici. Zabytkoznawstwo i Konserwatorstwo", 1980, t. 9, s. 41.

43 P. Buksalewicz, M. Gajdziński, K. Lutomski, op. cit., s. 109; W. Domasłowski, Konserwacja, s. 56; W. Domasłowski, K. Powidzki, op. cit., s. 194-195; W. Kurpik, Utwardzanie, s. 23; M. Paciorek, Badania, s. 50, 67, 88-89; idem, Zastosowanie tomografii komputerowej do badania rozmieszczenia i udziatu tworaywa w drewnie impregnowanym strukturalnie, „Biblioteka Muzealnictwa i Ochrony Zabytków”, 1992, seria B, t. 88, s. 212; idem, Zastosowanie tomografii komputerowej do badania rozmieszczenia $i$ udziału tworaywa w drewnie impregnowanym strukturalnie, „Ochrona Zabytków”, 1992, nr 3, s. 159; K. Sibul, op. cit., s. 3; W. Ślesiński, Konserwacja zabytkón sztuki, t. 2, s. 20; K. Wieczorek, op. cit., s. 80; E. de Witte, Resins in conservation: introduction to their properties and application, [w:] The proceedings of the symposium Resins in conservation beld at the University of Edinburgh 21st-22 ${ }^{\text {nd }}$ May 1982, Edinburgh 1998, s. 1-3. 
stanowi „dla impregnacji utwardzającej przypadek szczególnie złożony”, jak to trafnie ujął M. Paciorek ${ }^{44}$. Trudne jest więc oszacowanie udziału wprowadzonego tworzywa w poszczególnych strefach jego strukturalnej budowy.

\section{Przebieg i wyniki badania}

Próby doświadczalnego określenia rozłożenia żywicy w strukturze drewna podjęto $z$ zastosowaniem mikroskopii fluorescencyjnej. Jest to jedna z technik konwencjonalnej mikroskopii optycznej. Wykorzystuje ona zjawisko fotoluminescencji, zachodzące pod wpływem promieniowania ultrafioletowego (o długości fali 300-400 nm) ${ }^{45}$. Badanie wykonano na sezonowanym drewnie sosnowym, pochodzacym z obiektu zabytkowego, w którym zostało ono wtórnie użyte jako dodatkowy nośnik obrazu na płótnie. Było to drewno nieznacznie uszkodzone przez owady, jednak kostki o wymiarach $18-19 \times 48 \times 21 \mathrm{~mm}$ wycięto z miejsc nienoszących śladów żerowania. Użyto 10\% roztworu Paraloidu B-72 w toluenie z dodatkiem znacznika fluorescencyjnego - fioletu fluorescencyjnego ${ }^{46}$ w ilości $0,02 \% \mathrm{w}$ stosunku do masy roztworu. Zastosowano dwie metody nasycania - wznoszenia kapilarnego i zanurzenia (kapieli zimnej długo-

44 M. Paciorek, Badania, s. 58.

45 F. W. D. Rost, Fluorescence microscopy, vol. 1, Cambridge 1992, s. 1-2; Z. Rozłucka, J. Arszyńska, Mikroskopia fuorescencyjna UV w badaniach przelerojów warstw malarskich. Wplyw niektórych pigmentów na fuorescencje spoiw, „Biuletyn Informacyjny Konserwatorów Dzieł Sztuki”, 2003, nr 3-4, s. 13.

46 Fiolet fluorescencyjny - barwnik fluorescencyjny, naftalimid, emanator fluorescencyjny 331, firmy Kremer, o numerze katalogowym 94 730, dostępny w postaci żółtawo zabarwionego proszku. Katalog dystrybutora zalicza go do grupy barwników Lumogen, które - jak podaje - „Szczególnie dobrze jest [...] rozrabiać z bezbarwnymi lakierami na bazie tworzyw sztucznych, np. Paraloid B-72". Zob. Kremer Pigmente. Materialy dla konserwatorów zabytków, pozłotników i artystów plastyków, edycja polska 2005, s. 14. Wcześniejsza anglojęzyczna wersja katalogu, z której autorka korzystała w trakcie prowadzenia badań, zamieszczona na stronie internetowej http:/ / www.kremer-pigmente.de (dostęp: 21.01.2004), jako idealne spoiwo dla barwników tej grupy wymieniała Paraloid B-72 rozpuszczony w octanie etylu. 
trwałej). Przeprowadzono obserwacje makro- i mikroskopowe ${ }^{47} \mathrm{w}$ świetle widzialnym i ultrafioletowym płaszczyzn bocznych ${ }^{48}$ próbek oraz płaszczyzn przekroju poprzecznego dolnych, górnych i po przecięciu każdej kostki w połowie wysokości.

Uzyskane wyniki potwierdziły poważne nierównomierności przesycenia drewna. Obserwowano dużo większe nagromadzenie żywicy impregnatu $\mathrm{w}$ partiach przypowierzchniowych. Porównanie ze znacznie mniej lotnymi rozpuszczalnikami z grupy eterów glikolu propylenowego pozwoliło związać je ze zjawiskiem migracji powrotnej roztworu w toluenie - rozpuszczalniku o wysokiej lotności. Nie zaobserwowano także zależności równomierności przesycenia od zastosowanej metody nasycania. Ilustracją uzyskanych wyników sa przykładowe fotografie (zob. il. 1, 2) $)^{49}$.

47 Użyto mikroskopu fluorescencyjnego ECLIPSE 600, wyposażonego w obiektywy Nikon Plan Fluor. Może on pracować zarówno w świetle widzialnym, jak i ultrafioletowym. Do pracy w UV jest wykorzystywana zintegrowana z mikroskopem lampa rtęciowa Nikon Super HB 1010 AF. Do obserwacji fluorescencji próbek stosowano standardowy blok filtrów UV2A o następujących parametrach EX 330$-380 \mathrm{~nm}, \mathrm{DM} 400 \mathrm{~nm}, \mathrm{BA} 420 \mathrm{~nm}$. Dla obserwacji próbek w świetle widzialnym wykorzystywano zewnętrzny, stereoskopowy, światłowodowy oświetlacz halogenowy. Opis sprzętu za: Z. Rozłucka, M. Roznerska, J. Arszyńska, Mikroskopia fluorescencyjna. Zastosowanie w badaniu budony i procesón konserwatorskich malarstwa sz̨talugowego, Toruń 2000, s. 36.

48 Pojęciem boku próbki autorka posługuje się z pełną świadomością, że jest ono niepoprawne w odniesieniu do kostek drewna, ponieważ jednak próbki pozyskano z zabytkowych desek, dlatego ułożenie usłojenia było w nich losowe, stąd określenie „bok” próbki, jako odróżnienie od płaszczyzny przekroju poprzecznego, zamiast niemożliwego w tym wypadku oznaczenia typu przekroju (styczny, promieniowy).

49 Zdjęcia wykonała dr Zuzanna Rozłucka w Zakładzie Konserwacji Malarstwa i Rzeźby Polichromowanej UMK za pomoca zintegrowanego z mikroskopem automatycznego urządzenia fotograficznego Nikon H-III. Opis sprzętu podaję za: Z. Rozłucka, M. Roznerska, J. Arszyńska, op. cit., s. 38. Używano negatywów KODAK Gold 200 do światła dziennego. 


\section{Badanie wpływu toluenu i zawierających ten rozpuszczalnik roztworów impregnacyjnych na warstwy zapraw i polichromii obiektów zabytkowych}

W badaniach wykorzystano fragmenty drewna pokrytego warstwami zapraw i polichromii, pochodzącego z obiektów zabytkowych. Były to części konstrukcji wyposażenia kościelnego, zbyt zniszczone, aby dalej spełniać swoją funkcję, albo też elementy wprowadzone do obiektów wtórnie, których dalsza w nich obecność, po przeprowadzeniu prac konserwatorskich, nie znajdowała uzasadnienia ${ }^{50}$.

W badaniu wpływu impregnatów na warstwy zapraw i polichromii szczególną uwagę skierowano na określenie granic bezpiecznego stosowania rozpuszczalnika. Było to przyczyną użycia roztworów tylko jednej żywicy - Paraloidu B-72, jak też przeprowadzenia nasycania samym tylko rozpuszczalnikiem w celu zintensyfikowania obserwowanych $\mathrm{w}$ trakcie badań prawidłowości. Użyto:

- 10\% roztworu Paraloidu B-72 w toluenie $z$ dodatkiem fioletu fluorescencyjnego w ilości 0,02\% w stosunku do masy roztworu,

- 10\% roztworu Paraloidu B-72 w toluenie bez dodatku znacznika,

- toluenu.

Wykorzystanie do impregnacji samych tylko rozpuszczalników nie ma oczywiście zastosowania w praktyce konserwatorskiej. W przedstawionych tu badaniach dało możliwość określenia znaczenia udziału żywic w roztworze dla wielkości nieporządanych, ubocznych efektów nasycania. Wszystkie próbki impregnowano przez zanurzenie na okres 24 godzin (kapiel zimna długotrwała).

\section{Badania zmian wyglądu warstw zapraw i polichromii}

Stosowane w zabiegu impregnacji wzmacniającej roztwory nie pozostaja bez wpływu na warstwy zabytkowych polichromii. Wymagana jest bezbarwność żywicy oraz wybór rozpuszczalnika o jak najmniejszych właściwościach ekstrakcyjnych w stosunku do składników drewna. Eks-

50 Poszczególne próbki zostaną omówione w momencie przywoływania uzyskiwanych dla nich wyników. 
trakcja wosków, tłuszczów, wyższych kwasów tłuszczowych, aldehydów, ketonów, cukrów prostych, garbników, barwników, żywic i kwasów żywicznych powoduje nie tylko zmiany zabarwienia warstw przypowierzchniowych, zaprawy i warstwy malarskiej, ale także prowadzi do usunięcia $z$ drewna części jego naturalnych składników ochronnych ${ }^{51}$.

Literatura omawiająca to zagadnienie nie jest bogata i nie daje odpowiedzi na pytanie o zależność między właściwościami rozpuszczalnika a wielkością ekstrakcji, jaką powoduje. Poszukiwali jej M. Paciorek i P. Karaszkiewicz. Brali oni pod uwage stałą dielektryczną, stopień spęcznienia drewna, parametr rozpuszczalności $\delta$ i parametry rozpuszczalności według Teasa. W przeprowadzonych badaniach spektrofotokolorymetrycznych, porównując transmitancję poszczególnych ekstraktów, podzielili rozpuszczalniki na trzy grupy. Pierwsza to te o silnych właściwościach ekstrakcyjnych, czyli o małej transmitancji wynikającej z silnego zabarwienia roztworów po zabiegu. Należą do niej octan etylu, dwumetylosulfotlenek i trójchloroetylen. Druga obejmuje rozpuszczalniki o umiarkowanych właściwościach ekstrakcyjnych. Są to między innymi często stosowane toluen i ksylen, a także benzen i czterochlorek węgla. Trzecią stanowią ciecze o małej ekstraktywności, których przykładami są terpentyna i woda. Autorzy ci nie stwierdzili istotnej korelacji pomiędzy stałymi fizycznymi rozpuszczalników i ich ekstraktywnością. Badania chromatograficzne, jak podaja, również nie przyniosły dodatkowych informacji ${ }^{52}$. Przypuszczalnym wyjaśnieniem jest ich zdaniem zarówno skomplikowany skład ekstraktów, jak i ich nierównomierne rozłożenie w drewnie oraz reakcje zachodzące między rozpuszczalnikami i składnikami drewna ${ }^{53}$. M. Paciorek wskazuje jednak, że większa absorpcja przez drewno rozpuszczalników polarnych,

51 P. Buksalewicz, M. Gajdziński, K. Lutomski, op. cit., s. 108; W. Domasłowski, K. Powidzki, op. cit., s. 193; P. Karaszkiewicz, M. Paciorek, Badanie własności ekstrakcyjnych rozpuszczalników stosowanych w metodzie próżniowej impregnacji drewna, [w:] Chemia w konserwacji zabytków, s. 30; H. Krach, Środki i metody chemicznej konserwacji drewna w budowlach zabytkowych, Zagadnienia konserwacji drewna, „Biblioteka Muzealnictwa i Ochrony Zabytków", 1961, seria B, t. 3, s. 85; S. M. Nakhla, op. cit., s. 38; M. Makowska, op. cit., s. 53; M. Mietlicka, op. cit., s. 58; B. Soldenhoff, W zmacnianie drewna roztworami, s. 83; K. Wieczorek, op. cit., s. 79.

52 P. Karaszkiewicz, M. Paciorek, op. cit., s. 30-32; M. Paciorek, Badania, s. 21.

53 P. Karaszkiewicz, M. Paciorek, op. cit., s. 32-33. 
powodując większe jego spęcznienie, ułatwia przechodzenie do roztworu większych ilości substancji rozpuszczalnych, mimo że ich rodzaj i ilość nie maja jednoznacznego związku z wielkością spęcznienia. Kontynuując tę myśl, autor ten podkreśla dużą różnorodność oddziaływań cieczy organicznych i nieorganicznych na drewno oraz selektywne możliwości rozpuszczania i ekstrakcji poszczególnych substancji w wodzie oraz rozpuszczalnikach organicznych. Zwraca także uwagę, że na wielkość ekstrakcji mają wpływ nie tylko selektywne właściwości rozpuszczalnika, ale również warunki, w jakich ona przebiega, między innymi udział takich czynników, jak temperatura, ciśnienie, promieniowanie itp. ${ }^{54}$ Wśród indywidualnych cech drewna, kształtujących nie tyle wielkość ekstrakcji, ile intensywność zmian barwnych roztworu, należy wyróżnić charakter i stopień jego zniszczenia ${ }^{55}$, przykładowo, przez impregnat moga być rozpuszczane produkty rozkładu brunatnego $z$ wewnętrznych partii drewna, które migrując do powierzchni, moga powodować ciemne przebarwienia ${ }^{56}$.

Mówiąc o negatywnym wpływie stosowanych rozpuszczalników impregnatów na warstwy zapraw i polichromii, należy, oprócz zmian kolorystycznych, przypomnieć ich chemiczne oddziaływanie na spoiwa. Dotyczy to szczególnie rozpuszczalników niebędących węglowodorami, zawierających w swych cząsteczkach atomy tlenu ${ }^{57}$.

Intensywność powstających, w wyniku ekstrakcji rozpuszczalnych składników drewna, zmian barwnych warunkuje między innymi kolorystyka opracowań powierzchni. Określeniu wielkości zmian służyły przeprowadzone obserwacje makro- i mikroskopowe, a także wykonane pomiary spektrofotometryczne.

$\mathrm{Na}$ potrzeby obserwacji mikroskopowych, przed przystapieniem do badań, z warstw zapraw i polichromii wszystkich wykorzystanych tu desek pobrano próbki i wykonano naszlify. Kolejne próbki pobrano 160 dni po zakończeniu nasycania. Obserwacje mikroskopowe przekrojów poprzecznych przeprowadzono w świetle widzialnym i ultrafioletowym. Zilustro-

54 M. Paciorek, Badania, s. 21.

55 M. Mietlicka, op. cit., s. 21; E. Schaffer, Consolidation of painted wooden artifacts, „Studies in Conservation”, 1974, no. 4, s. 213.

56 E. Schaffer, op. cit., s. 213.

57 J. Ciabach, Badania, s. 72; idem, Damara, s. 15; M. Paciorek, Badania, s. 13. 
wano je wykonana dokumentacja fotograficzna poszerzona zdjęciami próbek. Dalej zostana również zaprezentowane przykładowe ilustracje zmian zabarwienia roztworów użytych do nasycania, zarówno wykorzystanych na tym etapie fragmentów drewna polichromowanego, jak i użytych wcześniej próbek niepolichromowanych.

Pomiary spektrofotometryczne wykonano spektrofotometrem odbiciowym o geometrii sferycznej d/8 X-Rite SP6458. Średnica pola pomiarowego wynosiła $8 \mathrm{~mm}$, stosowano iluminant $\mathrm{D}_{65}^{59}$, obserwator standardowy normalny (kąt widzenia) $10^{\circ}$. Mierzono próbki w zakresie spektralnym 400-400 nm, co $10 \mathrm{~nm}$.

Ewaluacji barw dokonywano w układzie CIELAB, posługując się układem współrzędnych kartezjańskich $\mathrm{L}^{*} \mathrm{a}^{*} \mathrm{~b}^{*}$, używanym powszechnie do określania barw na podstawie pomiarów składowych trójchromatycznych, a także układem współrzędnych cylindrycznych $\mathrm{L}^{*} \mathrm{C}^{*} \mathrm{~h}^{* 60}$. Przestrzeń barw CIELAB jest trójwymiarowa, w przybliżeniu równomierna ${ }^{61}$, utworzona przez naniesienie we współrzędnych prostokątnych wielkości

58 Pomiary wykonała dr Elżbieta Szmit-Naud w Zakładzie Konserwacji Malarstwa i Rzeźby Polichromowanej UMK w Toruniu.

59 Iluminant jest definiowany jako promieniowanie o względnym rozkładzie widmowym energii określonym w zakresie długości fal zdolnych do wywierania wpływu na postrzeganie barwy obiektu, natomiast iluminanty normalne CIE to iluminanty A, B, C, D 65 i inne iluminanty D (światła dziennego), które zostały określone przez CIE. Iluminant $\mathrm{D}_{65}$ reprezentuje fazę światła dziennego o temperaturze barwowej najbliższej 6504 K. Zob.: PN-89/E-04042/01 Pomiary promieniowania optycznego. Pomiary kolorymetryczne. Postanowienia ogólne, s. 4; PN-90/E-01005 Technika świetlna. Terminologia, s. 19.

60 A. Christment, Color \& Colorimetry, Paris 1998, s. 19, 21; E. Szmit-Naud, Wrażenie barmy i klasyfikacja barw. Ocena zmian barwy materiatón stosowanych w konserwacji $i$ restauracji dziet sztuki, „Acta Universitatis Nicolai Copernici. Zabytkoznawstwo i Konserwatorstwo", 2005, t. 34, s. 49, 59; eadem, Uzupetnianie, s. 83.

61 Według PN-89/E-04042/01, s. 6, i PN-90/E-01005, s. 23, równomierna przestrzeń barw to przestrzeń barw, w której równe odległości mają na celu odwzorowanie progowych lub nadprogowych różnic barw jednakowego rozmiaru. W równomiernej przestrzeni barw różnica między dwoma bodźcami barwowymi jest określana jako odległość między punktami odwzorowującymi te bodźce przy założeniu, że rozważana przestrzeń barw jest przestrzenią euklidesową. 
$L^{*}, a^{*}, b^{*}$, gdzie L* oznacza jasnośćć ${ }^{62}, a^{*}$ i b* określaja chromatycznośćc ${ }^{63}$ : $a^{*}$ czerwono-zieloność, b* żółto-niebieskawośćc ${ }^{4}$. Układ kartezjańskich współrzędnych można przedstawić również w postaci współrzędnych cylindrycznych $L^{*} C^{*} h^{*}$, gdzie $L^{*}$, jak powyżej, oznacza jasność, $C^{*}$ to nasycenie barwy (chroma), a h* to kat odcienia ${ }^{65}$.

Do pomiarów spektrofotometrycznych wykorzystano dwie serie próbek, wykonanych z wtórnego sosnowego podobrazia pokrytego zaprawą $a^{66}$ impregnowane roztworem Paraloidu B-72 z dodatkiem fioletu fluorescencyjnego oraz nasycane samym rozpuszczalnikiem. Każdorazowo pomiary wykonywano trzykrotnie na fragmentach próbek o różnej intensywności zaplamień.

\section{Omówienie uzyskanych wyników}

Badania wykazały i potwierdziły szkodliwe oddziaływanie toluenu na warstwy zapraw i polichromii.

$\mathrm{Na}$ wstępie stwierdzono, że proste testy polegające na nanoszeniu na powierzchnię próbki rozpuszczalnika nie dały odpowiedzi na pytanie o odporność warstw zapraw i polichromii na jego działanie długotrwałe, które następuje w przypadku impregnacji.

${ }^{62}$ Jasność jest ilościową cechą barwy i określa udział barw achromatycznych, poczynając od idealnej bieli aż do zupełnej czerni. Zob. definicje pojęcia zawarte w: J. Gronowska, Podstawy fizykochemii barwników, Torun 1997, s. 13; PN-90/E-01005, s. 14; E. Szmit-Naud, Wrażenie, s. 42.

63 Pojęcie chromatyczności łączy w sobie dwie cechy barwnego wyglądu światła: odcień i nasycenie. Odcień jest jakościowa cechą barwy. Jest to ta właściwość wrażenia wzrokowego, która powoduje, że barwa obserwowanej powierzchni wydaje się podobna do jednej z barw postrzeganych - czerwonej, żółtej, zielonej lub niebieskiej - albo kombinacji dwóch z nich. Nasycenie definiuje czystość danej barwy, określa procentową zawartość odcienia (koloru) w barwie jako słaby, mocny lub też blady, głęboki. Zob. definicje pojęć zawarte w: J. Gronowska, op. cit., s. 13; PN-90/E-01005, s. 15; E. Szmit-Naud, Wrażenie, s. 42.

64 A. Christment, op. cit., s. 19; E. Szmit-Naud, Wrażenie, s. 48.

65 A. Christment, op. cit., s. 22-23; E. Szmit-Naud, Wraženie, s. 48-49, 59; PN-89/E-040452/01, s. 6-7; PN-90/E-01005, s. 24.

66 Deska ta, do momentu przeprowadzenia prac konserwatorskich, funkcjonowała wtórnie w ołtarzu jako ślepe krosna, do których przybito obraz na płótnie. 
W trakcie wspomnianych testów nie zaobserwowano powstawania zmian barwnych. Pozwala to na stwierdzenie, że zaplamienia uwidaczniające się w trakcie i po zabiegu są wynikiem ekstrakcji i wyprowadzania na powierzchnię rozpuszczalnych składników drewna.

Proces ekstrakcji, przejawiający się zmiana zabarwienia roztworu, obserwowano już podczas zanurzenia w impregnacie (il. 3).

Wielkość zmian barwy roztworów toluenowych, pozostających po każdym przeprowadzonym zabiegu, jest różna. Zależy zapewne od zawartości substancji barwnych, bądź to naturalnych składników drewna, bądź produktów jego rozkładu (il. 4-6).

W przypadku roztworów zaobserwowano zagęszczanie i gromadzenie się migrującej wraz z rozpuszczalnikiem żywicy tuż pod powierzchnia zaprawy lub polichromii. Zjawisko to w pewnym stopniu spowalnia i ogranicza odparowywanie rozpuszczalnika przez warstwę malarską. Jednocześnie wyraźne jest hamujące działanie zagęszczającego się w tym miejscu żelu impregnatu na powstawanie na powierzchni zaprawy lub polichromii zmian kolorystycznych. Ekstrahowane barwne składniki drewna pozostają w żelu żywicy. Prawidłowość tę obserwowano szczególnie wyraźnie na przykładzie próbek wykonanych $z$ wtórnego sosnowego podobrazia, pokrytych jedynie warstwa jasnej zaprawy (il. 7).

Aby potwierdzić hipotezę o hamującym wpływie zagęszczającego się na granicy materiałów o różnej porowatości żelu impregnatu na migrację do powierzchni substancji barwnych, serię analogicznych próbek nasycono toluenem. Rezultaty eksperymentu, przedstawione na il. 8 i 9, oraz wyniki pomiarów spektrofotometrycznych (tab. 1) potwierdziły te przypuszczenia.

Dla obu badanych przykładowych próbek mierzone parametry uległy zmianom. Ich zakres był zdecydowanie mniejszy dla próbki impregnowanej roztworem żywicy niż dla nasycanej samym rozpuszczalnikiem. W próbce drugiej zanotowano większy spadek jasności (pociemnienie w kierunku czerni). Większe jest też $\Delta \mathrm{a}^{*}$, co oznacza zmianę barwy w kierunku czerwieni. Potwierdza to wynik pomiarów kąta odcienia, którego wartość, dla próbki 2 , nieco bardziej oddala się od $90^{\circ}$. Rozpatrując zmiany barwy na osi żółto-niebieskawość, wyrażone przez $\Delta \mathrm{b}^{*}$, również większe stwierdzono dla próbki 2. Analogicznie kształtuje się zróżnicowanie wielkości zmian nasycenia barwy (chroma). Wskazuje to na bardziej 
znaczący wzrost nasycenia koloru zaprawy próbki poddanej działaniu samego rozpuszczalnika. Zarejestrowano dla niej także większą całkowitą zmianę barwy $\Delta \mathrm{E}^{*}$.

Podsumowując wyniki pomiarów, należy stwierdzić, że każda z notowanych wartości była wyższa dla próbki 2 , co potwierdza fakt ograniczania, przez tworzący się pod powierzchnią zaprawy bądź polichromii żel impregnatu, powstawania zmian kolorystycznych. Ekstrahowane barwne składniki drewna pozostają w tworzącym się żelu żywicy.

Zabieg impregnacji może powodować nie tylko zmiany kolorystyczne, zwłaszcza jasnych warstw, ale częstokroć również zmiany w ich strukturze. W obrazie makroskopowym może to być spęcznienie i spęcherzenie polichromii (il. 10), w obrazie mikroskopowym - zwiększenie porowatości (il. 11 i 12).

\section{Badanie wpływu zabiegu nasycania próbek użytymi roztworami i rozpuszczalnikiem na temperaturę mięknienia warstwy malarskiej}

Wrażliwość warstwy malarskiej na działanie podwyższonej temperatury jest jej cechą charakterystyczna, zależna głównie od jej składu, a także od wilgotności otoczenia i tym samym od wilgotności równoważnej obiektu.

Temperatura mięknienia to taka wartość temperatury, w której warstwa malarska uplastycznia się na tyle, że staje się podatna na wszelkie trwałe odkształcenia. Wyznacza ona przede wszystkim granice bezpieczeństwa dla zabiegów konserwatorskich wymagających użycia ciepła oraz, co szczególnie istotne dla prowadzonych tu badań, jej zmiany pod wpływem wprowadzonych do obiektu środków, w tym również rozpuszczalników, informują o wielkości ich oddziaływania na wrażliwość termiczną warstw polichromii.

Pomiary wykonano za pomocą urządzenia TeRM. W trakcie badania stożkowa sonda aparatu, zakończona metalowym grotem, została ustawiona na powierzchni obiektu i naciskała na niego z określona, stała, wynosząca około 0,5 atm, siłą. Dzięki elektronicznemu układowi regulującemu jest ona w sposób płynny ogrzewana od temperatury otoczenia do $120^{\circ} \mathrm{C}$. W momencie osiąnięcia temperatury uplastycznienia badanej 
warstwy końcówka grota zaczyna się w niej zagłębiać. Jej ruch jest rejestrowany czujnikiem przesunięcia. Wartość widoczna w tym momencie na wyświetlaczu jest wartością temperatury mięknienia. Czas jednego pomiaru wynosi 5-10 s, po czym, przy tej samej temperaturze, pomiar powtarza się w innym miejscu ${ }^{67}$.

Pierwszy pomiar wykonano po 40 dniach, a kolejne co 20 dni, licząc od daty wyjęcia próbki z impregnatu. Przyjęto założenie, że nie tylko wielkość zanotowanej temperatury mięknienia jest miarą wpływu samego, czy też użytego w roztworze, rozpuszczalnika. Za równie istotny uznano czas, w przeciagu którego jego oddziaływanie utrzymuje się, oraz dynamikę całego procesu, określająca zmiany wielkości oddziaływania w wyznaczonym okresie. Uzyskane wyniki pomiarów przedstawiono w tab. 2 oraz na wykresie 1.

W przypadku dwustronnie polichromowanych desek ze schodów ambony temperatura mięknienia polichromii od strony lica stopni przed wykonaniem zabiegu mieściła się w granicach $80-83^{\circ} \mathrm{C}$. Po impregnacji największy jej spadek, do $36-42^{\circ} \mathrm{C}$, odnotowano w trakcie pomiaru wykonanego po 40 dniach. W kolejnych pomiarach obserwowano jej stopniowy wzrost, do ponad $70^{\circ} \mathrm{C}$ po 120 dobach. Od tego momentu notowane wartości wahały się pomiędzy 73 a $79^{\circ} \mathrm{C}$. Dla strony odwrocia desek wyjściowa temperatura mięknienia wynosiła $69-71^{\circ} \mathrm{C}$. Wartości zbliżone do wyjściowych uzyskano już po 60 dniach. Dla desek ołtarzowych przed zabiegiem jej wartości zawierały się w przedziale $76-79^{\circ} \mathrm{C}$. W trakcie pierwszego pomiaru po zabiegu wynosiła od 56 do $62^{\circ} \mathrm{C}$, a po 60 dniach przekroczyła $70^{\circ} \mathrm{C}$. Kostki wycięte z wtórnego, pokrytego jedynie zaprawa, podobrazia cechowała temperatura mięknienia w przedziale $78-85^{\circ} \mathrm{C}$. Połowę z nich nasycono jak powyższe $10 \%$ roztworem

67 B. J. Rouba, Badanie wražliwości warstw malarskich obrazón na džiałanie ciepla, „Ochrona Zabytków”, 1991, nr 4, s. 278-282; eadem, Budowa techniczna obrazón XIX-wiecznych malowanych na bandlowych podobraziach plóciennych i problematyka ich konserwacji, Torun 1988, s. 213; eadem, Zagadnienie beapieczeństwa obrazón XIX-i XX-wiecznych w procesie ich konserwacij, [w:] Zabytkoznawstwo i konserwatorstwo. Materialy ze zjazdu absolventón UMK w Toruniu, Torun, 14-15 XI 1985, pod red. S. Skibińskiego, „Biblioteka Muzealnictwa i Ochrony Zabytków", 1987, seria B, t. 81, s. 129-130; Untersuchung der Wärmeempfindlichkeit von Malschicbten, „Restauro”, 1992, Nr. 3, s. 148. 
Paraloidu B-72, połowę zaś czystym rozpuszczalnikiem. Dla próbek traktowanych roztworem najniższe wartości temperatury mięknienia zanotowano w trakcie pierwszego pomiaru. Wynosiły one od 36 do $43^{\circ} \mathrm{C}$. Temperatura powróciła do wartości wyjściowej po 100 dniach. Dla próbek nasycanych rozpuszczalnikiem mierzona temperatura była niższa pomiędzy 31 a $39^{\circ} \mathrm{C}$. Powróciła do wartości zbliżonych do wyjściowych po 160 dniach. Warstwa malarska dwustronnie polichromowanych desek z ławek również stała się mniej odporna na działanie ciepła. Przed zabiegiem jej temperatura mięknienia wynosiła od 73 do $77^{\circ} \mathrm{C}$. Po 40 dniach od zakończenia nasycania spadła do $25-31^{\circ} \mathrm{C}$ od strony lica i $20-30^{\circ} \mathrm{C}$ od strony odwrocia (zanurzonego w roztworze). W kolejnych pomiarach notowano jej stopniowy wzrost, nieco szybszy od strony lica, jednakże najwyższe wartości nie przekroczyły $56^{\circ} \mathrm{C}$.

\section{Wnioski końcowe}

Przeprowadzone badania po raz kolejny przypomniały i pogłębiły świadomość wad roztworów toluenowych. Szkodliwe działanie na warstwy zapraw i polichromii oraz fakt, że stosując je, trudno uzyskać równomierne i całkowite przesycenie wzmacnianych obiektów, zostały zilustrowane i tam, gdzie to możliwe, potwierdzone pomiarami.

Problem doskonalenia stosowanych środków impregnacyjnych, szczególnie w zakresie doboru używanych rozpuszczalników, pozostaje nadal otwarty. Warunkiem prawidłowo przeprowadzonej konserwacji jest bowiem, poza skutecznościa, bezpieczeństwo rozumiane jako niepowodowanie w obiekcie szkodliwych zmian, zarówno natychmiastowych, jak i odległych w czasie ${ }^{68}$. Dbając o dobro dzieła sztuki i przestrzegając podstawowej zasady „przede wszystkim nie szkodzić”, mamy, poza swoboda wyboru wykorzystywanych metod i środków, obowiązek dokonania go zgodnie $z$ istniejąca na ten temat wiedza, tak aby nie spowodowały one

68 B. J. Rouba, Zagadnienie, s. 127; eadem, Problem nowoczesnych technik $w$ driatalnosci konserwatorskiej, [w:] Lasery i inne techniki w konserwacji obiektón zabytkowych, Gdańsk 2002, s. 14. 
żadnych zniszczeń w obiekcie i nie były jednocześnie szkodliwe dla nas i środowiska ${ }^{69}$. Roztwory toluenowe, mimo że często brakuje dla nich lepszej alternatywy, w omówionych w artykule kilku aspektach oddziaływań impregnat-drewniany polichromowany obiekt zabytkowy nie spełniaja tych warunków.

Tab. 1. Wyniki pomiarów spektrofotometrycznych i ocena barwometryczna próbek, nasycanych roztworem Paraloidu B-72 i samym rozpuszczalnikem

\begin{tabular}{|c|c|c|c|c|c|c|c|c|c|c|}
\hline $\begin{array}{c}\text { Oznaczenie } \\
\text { próbki }\end{array}$ & $\mathrm{L}^{*}$ & $\mathrm{a}^{*}$ & $\mathrm{~b}^{*}$ & $\mathrm{C}^{*}$ & $\mathrm{hş}$ & $\Delta \mathrm{L}^{*}$ & $\Delta \mathrm{a}^{*}$ & $\Delta \mathrm{b}^{*}$ & $\Delta \mathrm{C}^{*}$ & $\Delta \mathrm{E}^{*}$ \\
\hline Próbka 0 & 79,17 & $+1,07$ & $+14,55$ & 14,59 & 85,81 & & & & & \\
\hline Próbka 1 & 78,18 & $+1,45$ & $+15,42$ & 15,48 & 84,64 & $-0,99$ & $+0,38$ & $+0,87$ & $+0,89$ & 1,37 \\
\hline Próbka 2 & 73,95 & $+2,17$ & $+19,83$ & 19,95 & 83,76 & $-5,22$ & $+1,10$ & $+5,28$ & $+5,36$ & 7,51 \\
\hline
\end{tabular}

Oznaczenia próbek użyte w tabeli:

próbka 0 - fragment sosnowego podobrazia pokrytego zaprawa, próbka wzorcowa, nieimpregnowana;

próbka 1 - fragment sosnowego podobrazia pokrytego zaprawa, impregnowany 10\% roztworem Paraloidu B-72 w toluenie z dodatkiem fioletu fluorescencyjnego w ilości $0,02 \%$ w stosunku do masy roztworu;

próbka 2 - fragment sosnowego podobrazia pokrytego zaprawa, nasycony toluenem.

69 K. Chmielewski, Uwagi do „Kodeksu etyki zawodowej konserwatorów dziet sz̨tuki”, „Biuletyn Informacyjny Konserwatorów Dzieł Sztuki”, 1998, nr 4, s. 21; E.C.C.O. Europejska Konfederacja Zwiazkón Konserwatorów-Restauratorów, „Biuletyn Informacyjny Konserwatorów Dzieł Sztuki”, 1998, nr 4, s. 25; J. Furdyna, Wybór wartości i inne zagadnienia teoretyczne w konserwacji dzieł sz̨tuki, „Biuletyn Informacyjny Konserwatorów Dzieł Sztuki”, 1998, nr 4, s. 13; B. J. Rouba, Potrzeba rozszerzenia Kodeksu Etyki Zawodowej, „Biuletyn Informacyjny Konserwatorów Dzieł Sztuki”, 1998, nr 4, s. 33; eadem, Zasady postępowania etycznego w ochronie dóbr kultury, „Biuletyn Informacyjny Konserwatorów Dzieł Sztuki”, 2000, nr 2, s. 84, 87; J. Wolski, Kodeks etyki zawodowej konserwatorów dziet squki, „Biuletyn Informacyjny Konserwatorów Dzieł Sztuki”, 1998, nr 4, s. 16; idem, Kodeks etyki zawodowej konserwatorów-restauratorów dzieł sztuki, „Biuletyn Informacyjny Konserwatorów Dzieł Sztuki”, 2000, nr 2, s. 91. 
Tab. 2. Wyniki pomiarów temperatury mięknienia warstw zapraw i polichromii próbek

\begin{tabular}{|c|c|c|c|c|c|c|c|c|c|c|c|}
\hline \multirow{2}{*}{$\begin{array}{c}\text { Określe- } \\
\text { nie } \\
\text { próbki }\end{array}$} & \multicolumn{10}{|c|}{$\begin{array}{c}\text { przed } \\
\text { impre- } \\
\text { gnacją }\end{array}$} & \multicolumn{10}{|c|}{ po impregnacji (w dobach) } \\
\hline 1 & $80-83$ & $36-42$ & $59-64$ & $63-68$ & $62-71$ & $73-75$ & $74-77$ & $74-78$ & $76-79$ & $76-79$ & $71-72$ \\
\hline 2 & $69-71$ & $52-56$ & $67-69$ & $68-70$ & $71-74$ & $75-79$ & $71-74$ & $73-74$ & $69-74$ & $73-74$ & $69-71$ \\
\hline 3 & $76-79$ & $56-62$ & $69-73$ & $69-74$ & $69-74$ & $68-73$ & $68-73$ & $69-73$ & $71-75$ & $71-76$ & $70-72$ \\
\hline 4 & $78-85$ & $36-43$ & $61-66$ & $61-72$ & $75-80$ & $77-81$ & $80-84$ & $78-80$ & $80-85$ & $78-85$ & $79-84$ \\
\hline 5 & $78-85$ & $31-39$ & $51-60$ & $62-68$ & $63-68$ & $60-70$ & $69-71$ & $75-78$ & $74-78$ & $75-79$ & $76-81$ \\
\hline 6 & $73-77$ & $25-31$ & $40-48$ & $45-50$ & $43-50$ & $45-51$ & $45-53$ & $42-53$ & $42-54$ & $43-56$ & $46-55$ \\
\hline 7 & $73-77$ & $20-30$ & $26-33$ & $42-49$ & $43-49$ & $42-49$ & $44-56$ & $44-56$ & $43-54$ & $41-53$ & $43-54$ \\
\hline
\end{tabular}

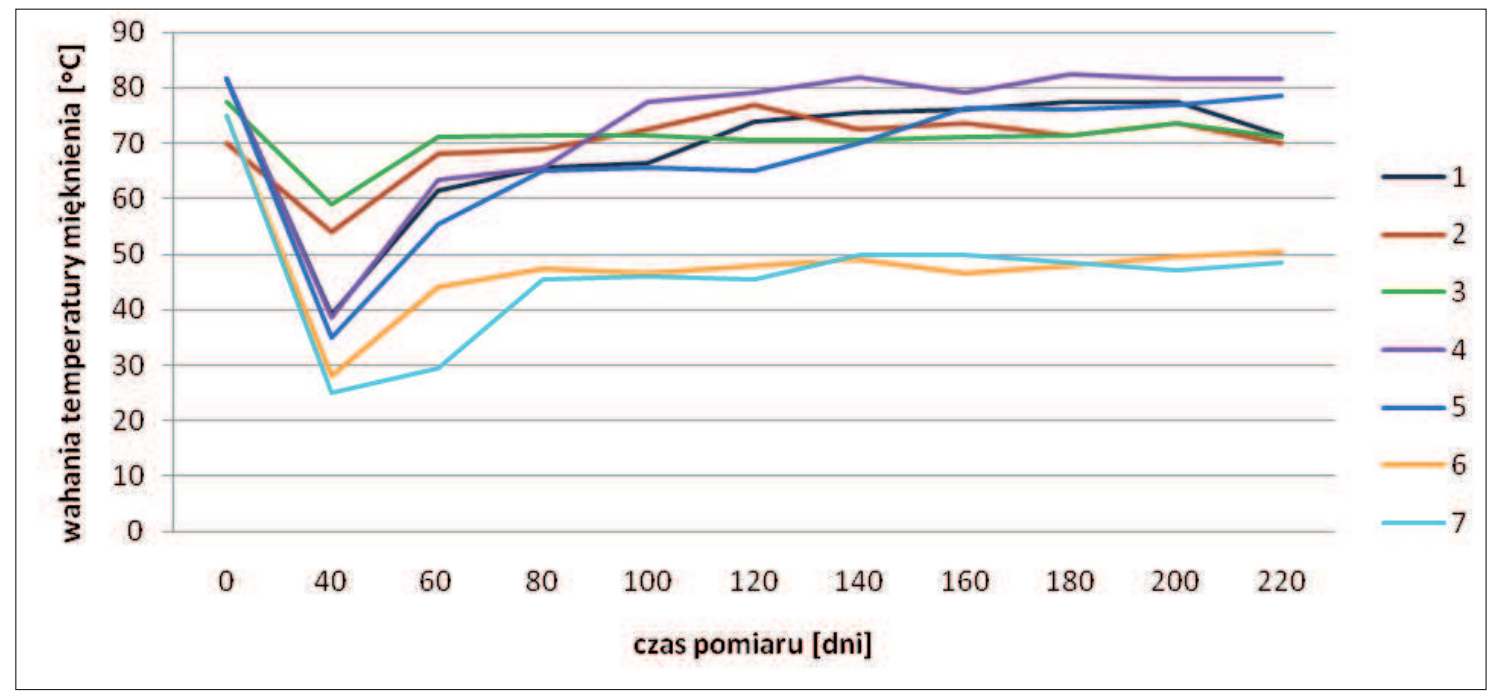

Wykres 1. Uśrednione wyniki pomiarów temperatury mięknienia warstw zapraw i polichromii próbek

Oznaczenia użyte w tab. 2 i na wykresie 1:

1 - próbka wykonana ze schodów ambony, strona lica, impregnowana 10\% roztworem Paraloidu B-72 w toluenie z dodatkiem fioletu fluorescencyjnego w ilości 0,02\% w stosunku do masy roztworu;

2 - próbka wykonana ze schodów ambony, strona odwrocia - w trakcie zabiegu zanurzona w roztworze, impregnowana 10\% roztworem Paraloidu B- $72 \mathrm{w}$ toluenie $\mathrm{z}$ dodatkiem fioletu fluorescencyjnego w ilości $0,02 \%$ w stosunku do masy roztworu;

3 - próbka wykonana z elementu konstrukcji ołtarza, impregnowana 10\% roztworem Paraloidu B-72 w toluenie $z$ dodatkiem fioletu fluorescencyjnego w ilości 0,02\% w stosunku do masy roztworu; 
4 - próbka wykonana z sosnowego podobrazia pokrytego zaprawa, impregnowana $10 \%$ roztworem Paraloidu B-72 w toluenie z dodatkiem fioletu fluorescencyjnego w ilości 0,02\% w stosunku do masy roztworu;

5 - próbka wykonana z sosnowego podobrazia pokrytego zaprawą, nasycana samym toluenem;

6 - próbka wykonana z dwustronnie polichromowanej deski z ławek, strona lica, impregnowana 10\% roztworem Paraloidu B-72 w toluenie;

7 - próbka wykonana z dwustronnie polichromowanej deski z ławek, strona odwrocia w trakcie zabiegu zanurzona w roztworze, impregnowana 10\% roztworem Paraloidu B-72 w toluenie.

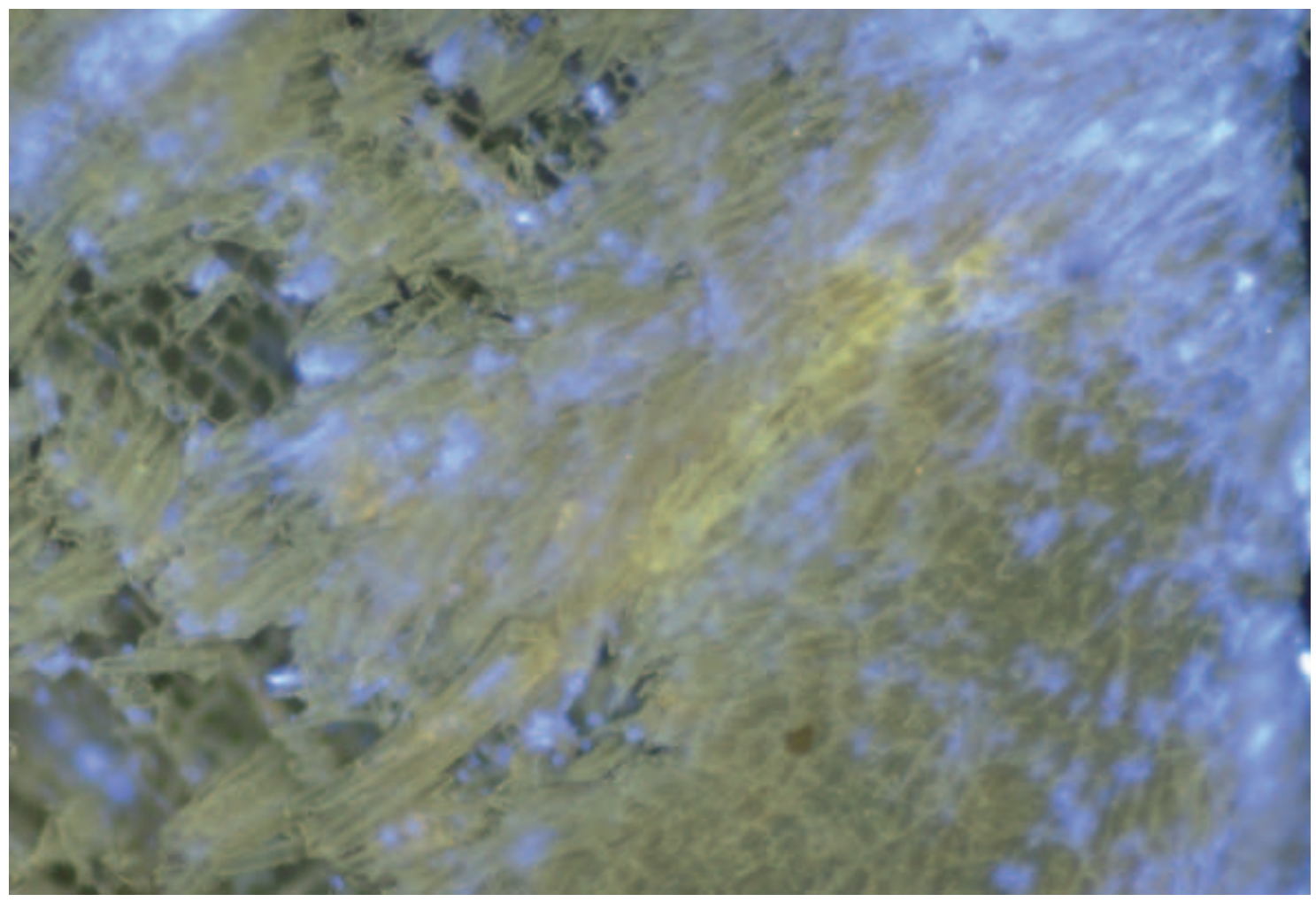

Il. 1. Fragment przekroju poprzecznego próbki nasycanej metodą wznoszenia kapilarnego po przecięciu jej w połowie wysokości, w świetle UV (80×) (fot. Z. Rozłucka)

Zdjęcie pozwala prześledzić rozmieszczenie impregnatu. Jego prawa krawędź pokrywa się z brzegiem próbki i właśnie ten fragment jest najsilniej przesycony - widać błękitna fluorescencję znakowanego impregnatu. W centralnej partii wprowadzona żywica wypełnia jedynie światło poszczególnych cewek. Widoczne żółtawe przebarwienia wskazują na obecność żywicy naturalnej rozpuszczanej podczas impregnacji przez użyty rozpuszczalnik 


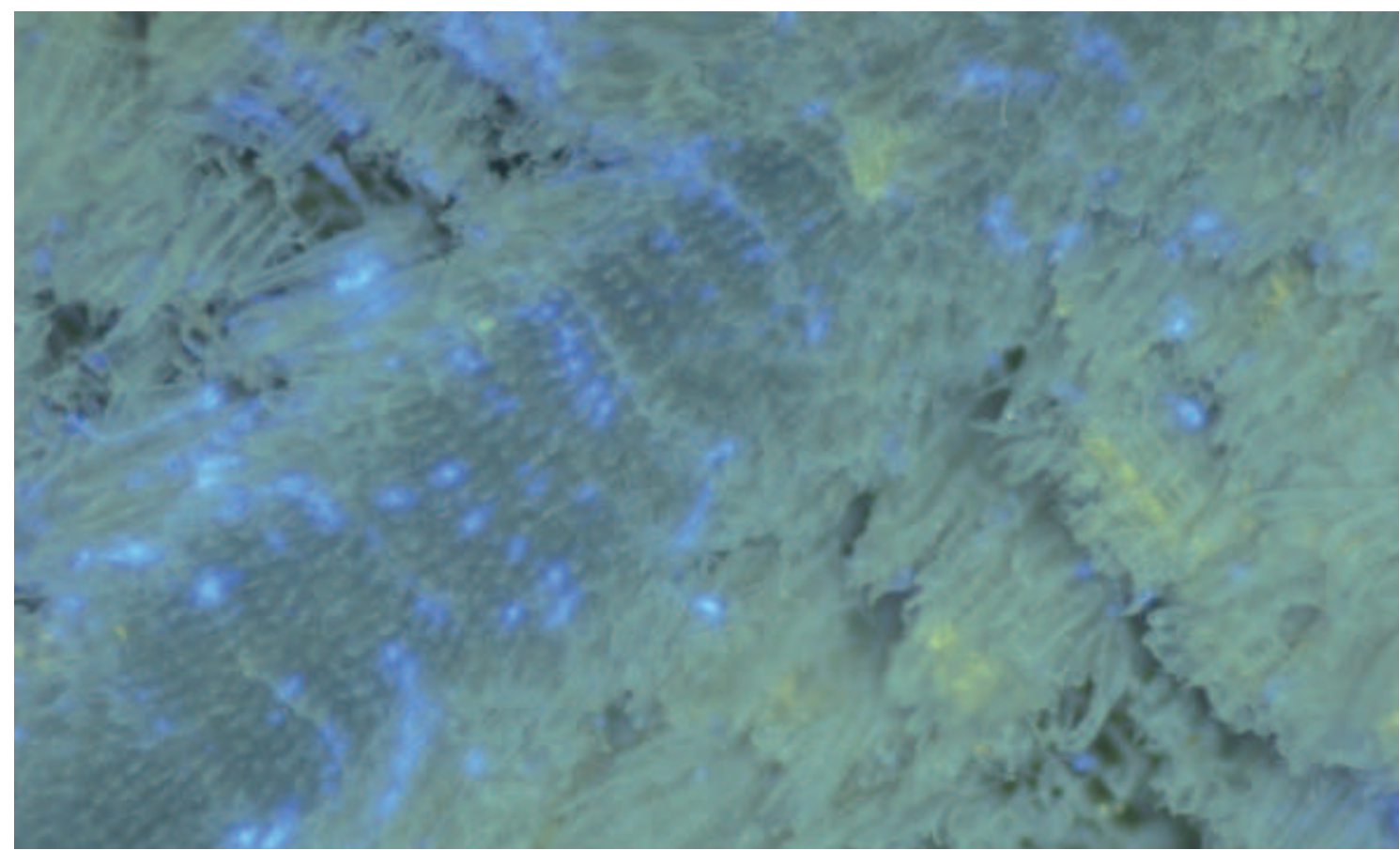

Il. 2. Fragment przekroju poprzecznego próbki nasycanej metodą zanurzenia (kapiel zimna długotrwała) po przecięciu jej w połowie wysokości, w świetle UV (80×) (fot. Z. Rozlucka)

Zdjęcie ukazuje środkowy fragment oglądanej płaszczyzny przekroju. Widać, że przesycenie drewna jest tu nieznaczne i nierównomierne. Skupiska żywicy impregnatu sa rozproszone, można zaobserwować wtrącenia rozpuszczanej przez toluen żywicy naturalnej

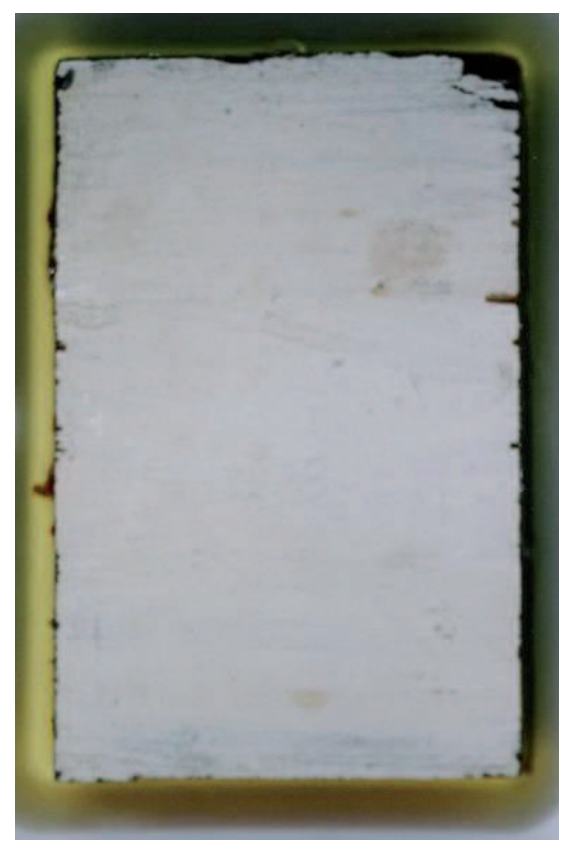

Il. 3. Próbka wykonana z sosnowego podobrazia, pokrytego jedynie zaprawa klejowo-kredową 24 godziny po zanurzeniu w 10\% roztworze Paraloidu B-72 w toluenie (fot. K. Szczepińska)

Widoczne jest lekkie zabarwienie roztworu impregnacyjnego 

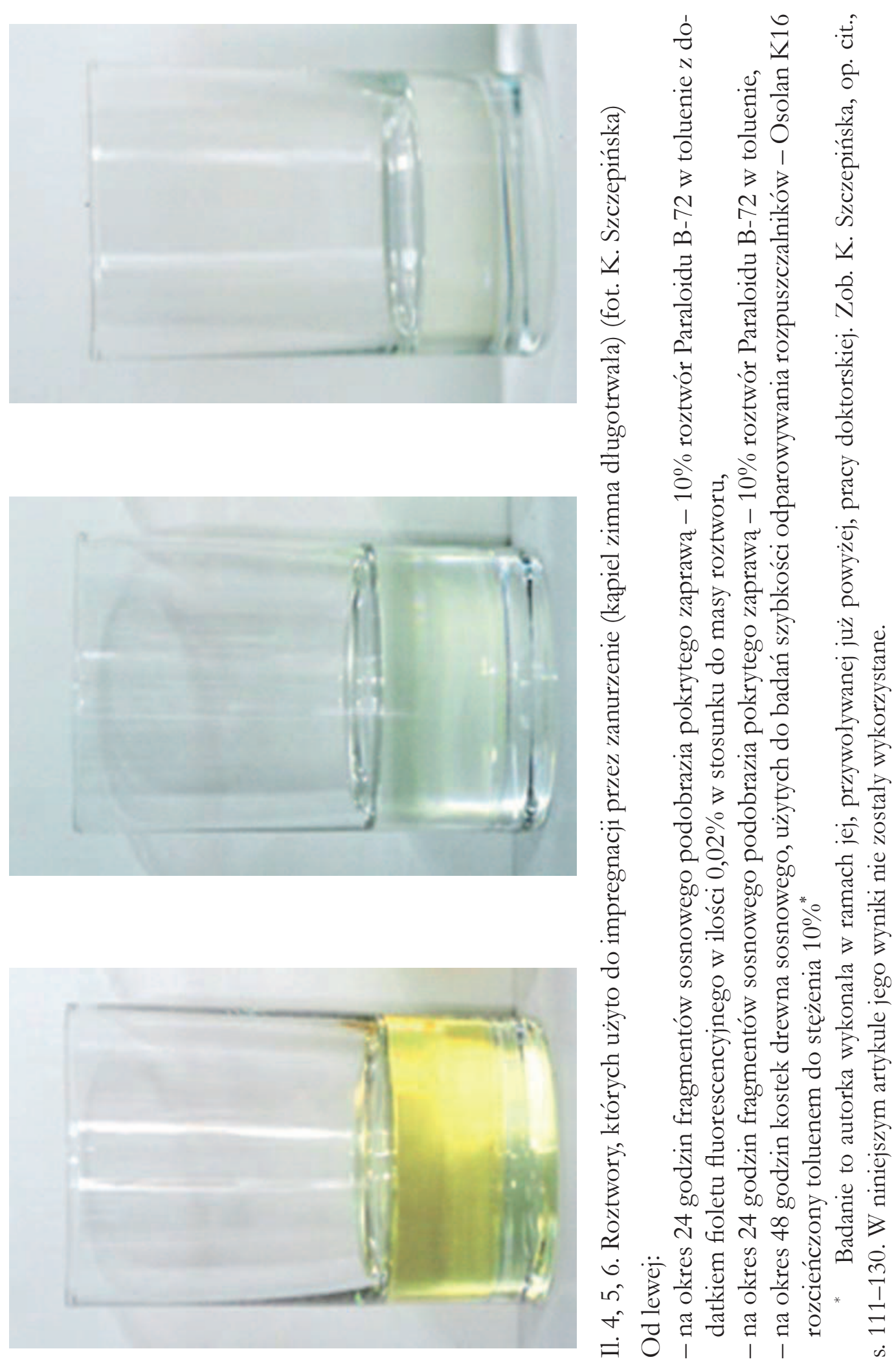

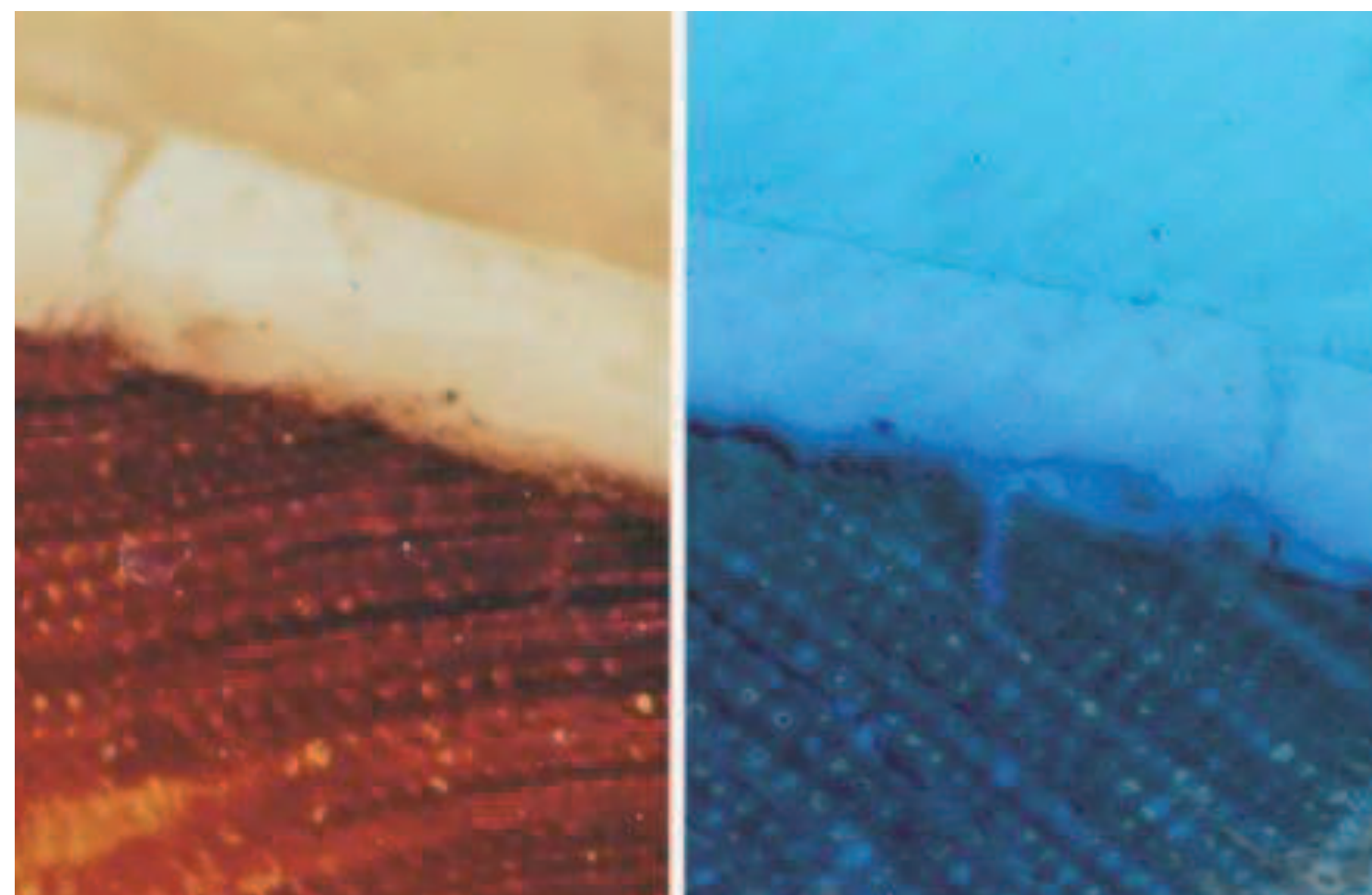

Il. 7. Przekrój stratygraficzny pokrytego zaprawą sosnowego podobrazia po impregnacji 10\% roztworem Paraloidu B-72 w toluenie. Fotografie w świetle widzialnym i promieniach UV (80×) (fot. Z. Rozłucka)

W świetle widzialnym nie zaobserwowano wyraźnych zmian kolorystycznych zaprawy. Obserwacje we fluorescencji UV potwierdzają to spostrzeżenie. Wyraźne jest przesycenie drewna impregnatem, gromadzącym się również pod powierzchnią zaprawy, co jest tu widoczne w postaci wyraźnej, błękitnej linii

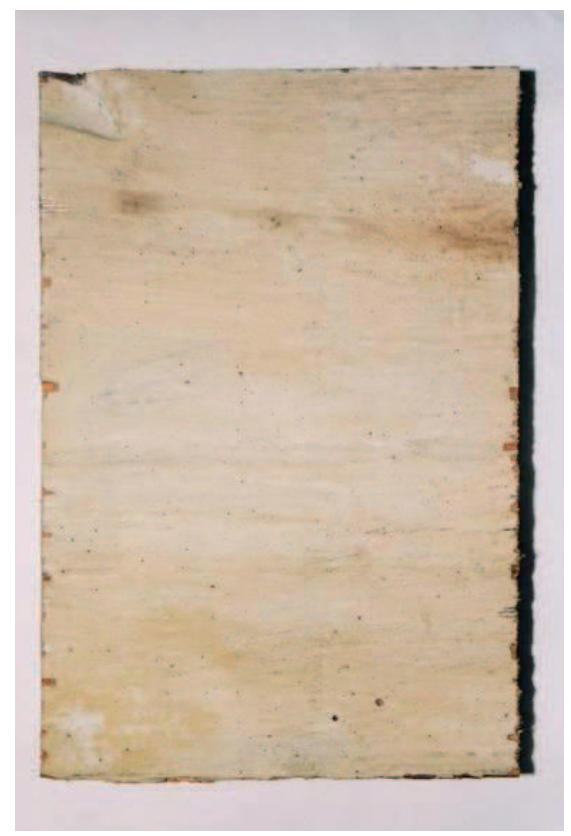

Il. 8. Próbka wykonana z sosnowego podobrazia pokrytego zaprawą 60 dni po zakończeniu 24-godzinnego nasycania toluenem (fot. K. Szczepińska)

Zaplamienia powierzchni są tu wyraźne 

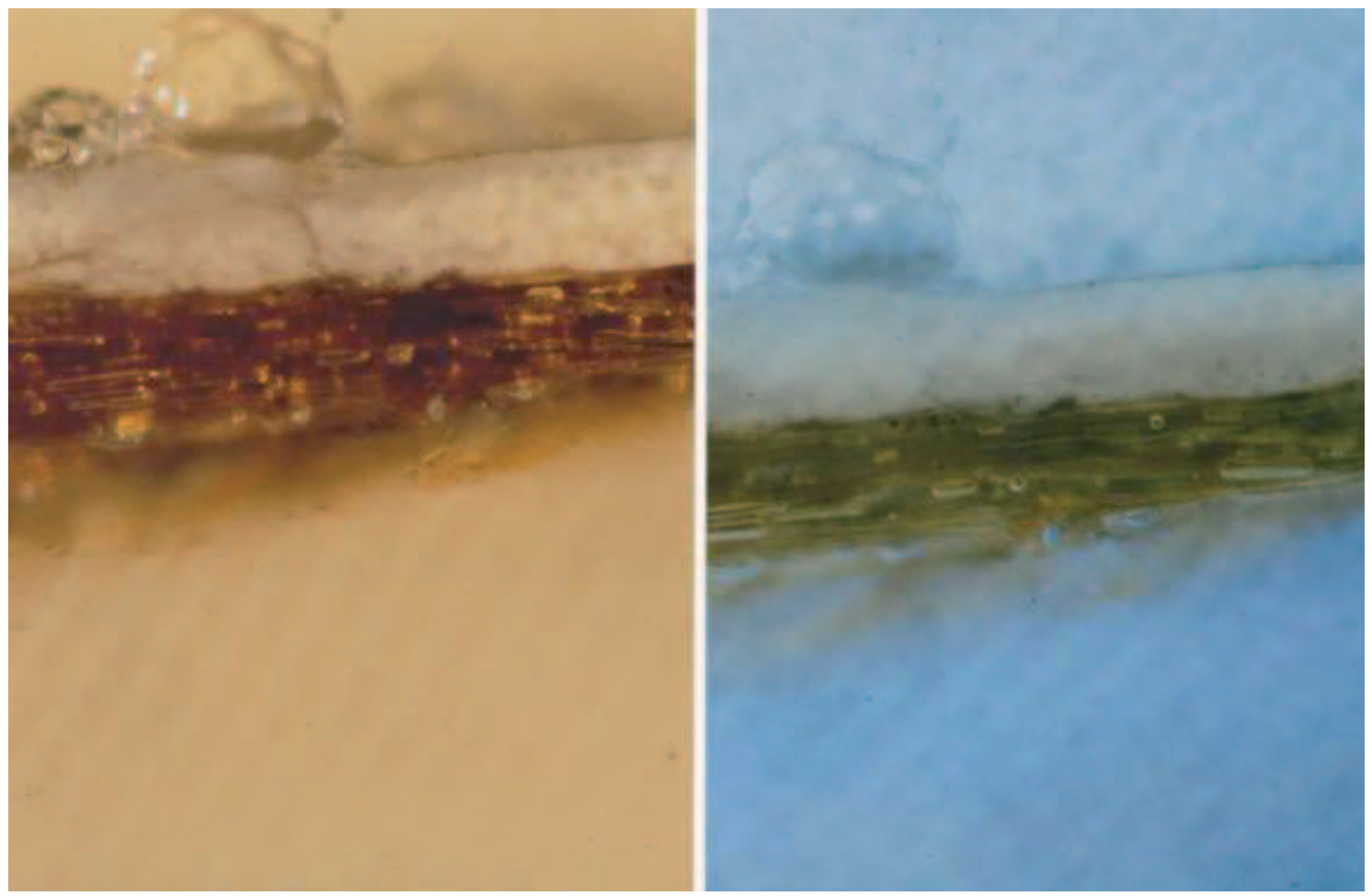

Il. 9. Przekrój stratygraficzny pokrytego zaprawą sosnowego podobrazia po nasyceniu toluenem. Fotografie w świetle widzialnym i promieniach UV (80×) (fot. Z. Rozłucka) W świetle widzialnym jest widoczne lekkie, brązowe zabarwienie zaprawy przy styku z drewnem oraz nieznaczne jej poszarzenie na powierzchni. W świetle UV szarobrązowe zabarwienie zaprawy do około połowy grubości jest bardzo czytelne

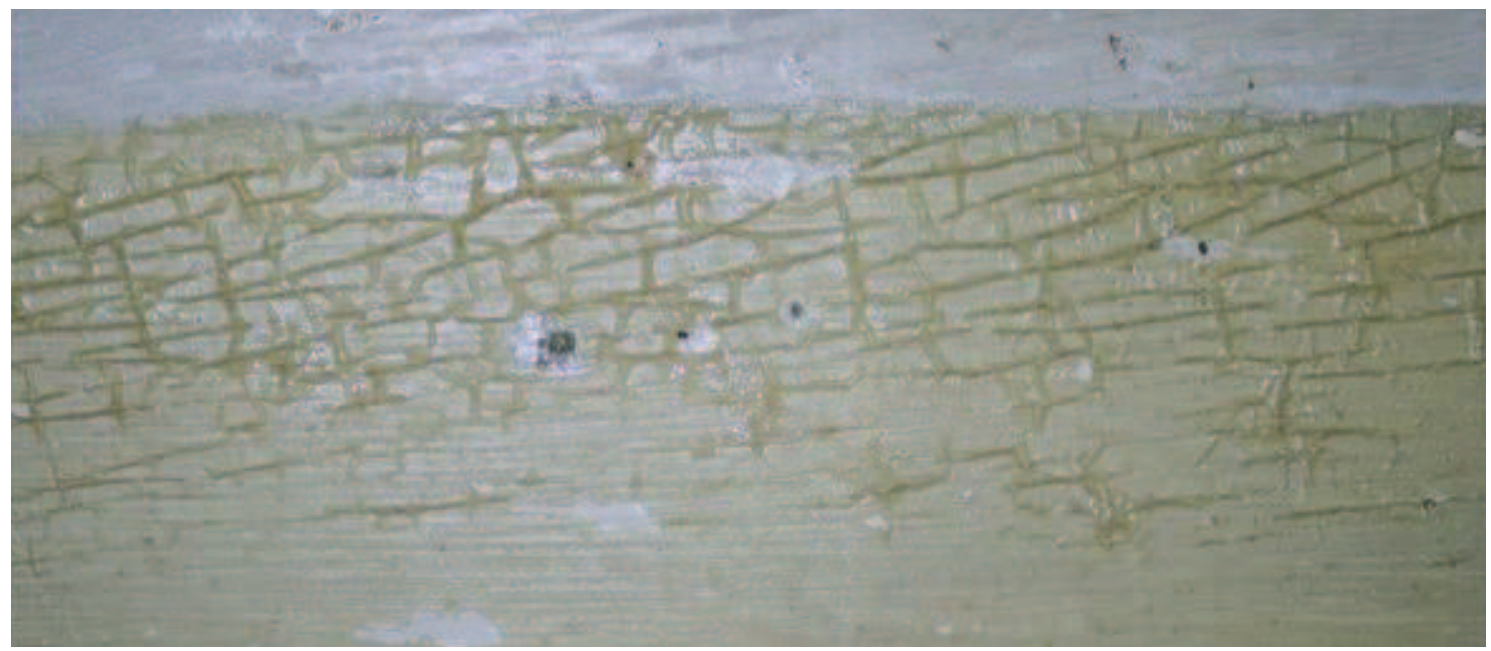

Il. 10. Fragment polichromowanej deski 24 godziny po zanurzeniu w 10\% toluenowym roztworze Paraloidu B-72 (fot. K. Szczepińska)

Deska pochodzi z elementu konstrukcyjnego ołtarza, datowanego na około $1730 \mathrm{r}$. Pokrywa ja warstwa białej zaprawy i żółtojasnozielonej polichromii, obie o charakterze emulsyjnym. Zdjęcie ukazuje powstałe silne spęcznienie i spęcherzenie polichromii 


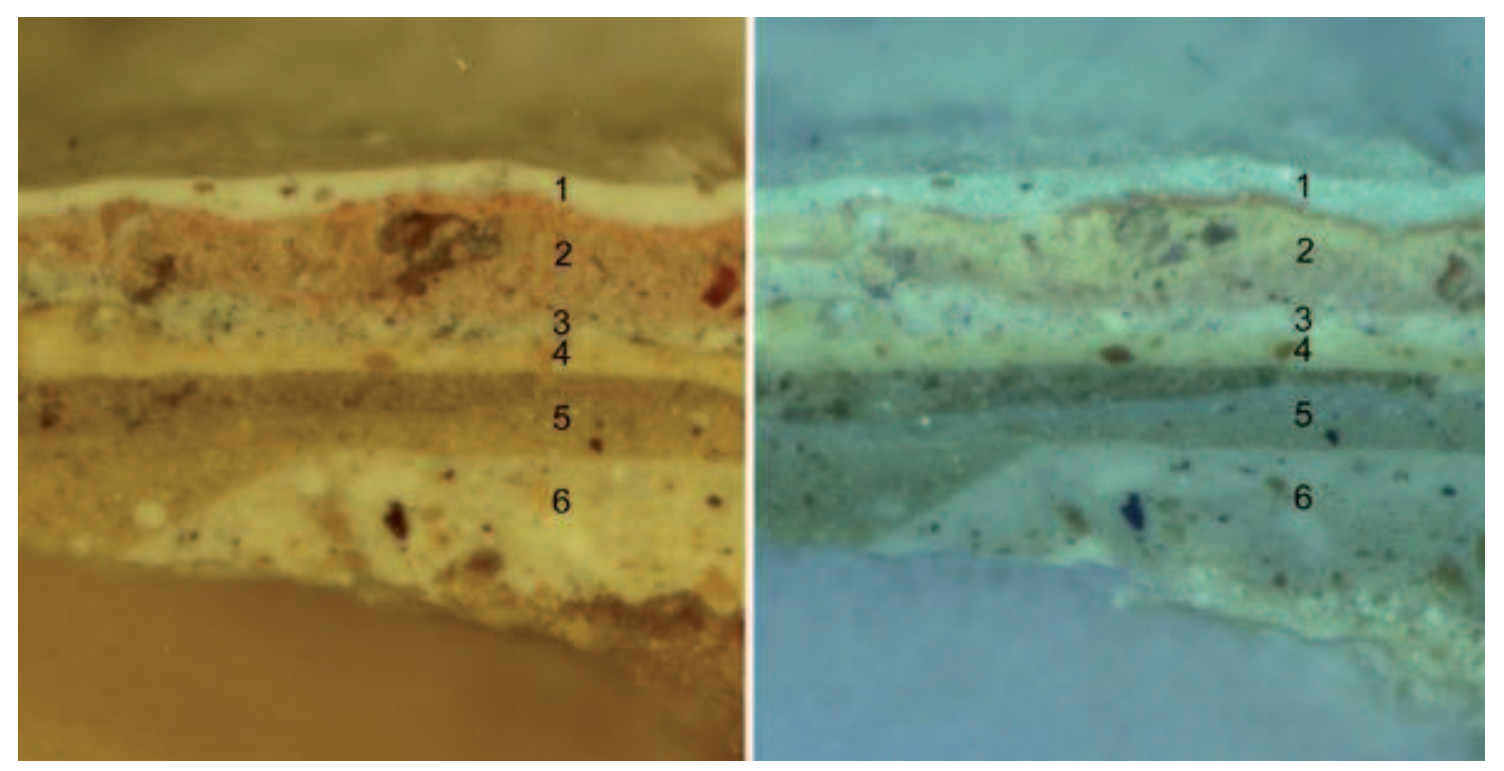

Il. 11. Próbka porównawcza. Przekrój stratygraficzny warstw polichromii przed impregnacją. Numerem 1 oznaczono warstwę najpóźniejszego chronologicznie przemalowania. Fotografie w świetle widzialnym i promieniach UV (80×) (fot. Z. Rozłucka)

Deska pochodzi ze stopni schodów ambony datowanej na XVIII w. Były one pokryte warstwą zaprawy klejowo-kredowej i pięcioma, różniącymi się kolorystycznie, warstwami polichromii, z których cztery pierwsze miały charakter emulsyjny, piąta to współczesne przemalowanie olejne 

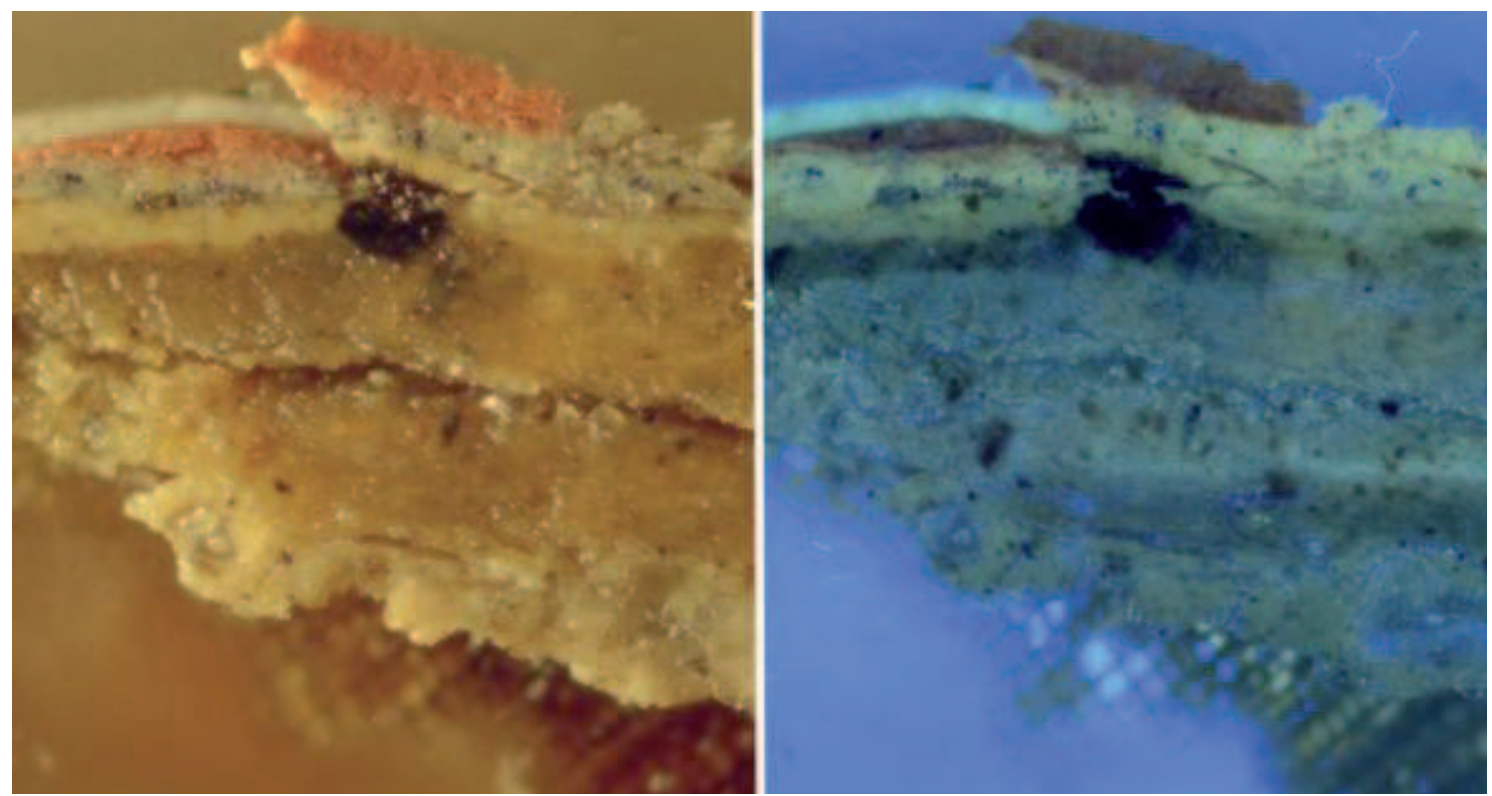

Il. 12. Przekrój stratygraficzny warstw polichromii powyższej deski po impregnacji $10 \%$ roztworem Paraloidu B-72 w toluenie z dodatkiem fioletu fluorescencyjnego w ilości $0,02 \% \mathrm{w}$ stosunku do masy roztworu. Fotografie w świetle widzialnym i promieniach UV (80×) (fot. Z. Rozłucka)

Struktura warstwy 2 wydaje się lekko rozluźniona. Warstwa 3, choć miejscami zachowała swoją odrębność i spoistość, jest częściowo wymieszana z warstwami sąsiadującymi. Warstwy 4 i 5 są rozspojone i nie tak zróżnicowane kolorystycznie jak przed nasycaniem, ich struktura nie jest tak zwarta. Struktura zaprawy wydaje się również bardziej porowata. We fluorescencji UV widać impregnat wypełniający wszelkie spękania i rozspojenia. Są nim przesycone także leżące bliżej drewna warstwy 6, 5 i 4 


\section{Summary}

\section{Some aspects of harmful effects of toluene's solutions used for strengthening impregnation treatment on antique wooden polychrome objects}

The article presents negative aspects of application of toluene, solvent commonly used for strengthening impregnation treatment, on polychrome wood. The reader is introduced with matter of impregnation and solvents applied to. Results of research concerning issues important for interaction between wood and impregnation solution are presented, laying stress on toluene.

Thanks to the UV-fluorescence microscopy method combined with the utilization of fluorescence markers of the applied solutions, the known fact of uneven consolidant distribution and it's higher concentration nearby the surface in case of toluene's solutions has been proved.

The tests were conducted on wood covered with layers of priming and paint allowed to observe considerable changes of polychromy colour, affected by extraction of coloured wood constituents, caused by toluene. The rate of colour changes was restricted a little by a geled resin, from the applied solution, that thickened on the border between wood and priming layer - two materials characterized by different porosity. The observations were supported by spectrophotometric measurement. Some structural changes in priming and painting layers, such as swelling, blistering and increase of porosity were also observed as well as significant and long-lasting decrease of their softening point. 